\title{
Cretaceous provenance change in the Hegang Basin and its connection with the Songliao Basin, NE China: evidence for lithospheric extension driven by palaeo-Pacific roll-back
}

\author{
MINGDAO SUN ${ }^{1,2,3}$, HANLIN CHEN $^{1 *}$, FENGQI ZHANG ${ }^{1}$, SIMON A. WILDE ${ }^{2}$, \\ A MINNA ${ }^{1},{\text { XIUBIN } \text { LIN }^{1} \text { \& SHUFENG YANG }}^{1}$ \\ ${ }^{1}$ Department of Earth Science, Zhejiang University, Hangzhou, Zhejiang 310027, China \\ ${ }^{2}$ Department of Applied Geology, Curtin University, Perth, WA 6845, Australia \\ ${ }^{3}$ Guangzhou Institute of Geochemistry, Chinese Academy of Sciences, \\ Guangzhou 510640, China \\ *Corresponding author (e-mail: hlchen@zju.edu.cn)
}

\begin{abstract}
The Cretaceous Hegang Basin is located on the Jiamusi Block, NE China, and separated from the Songliao Basin by the Lesser Xing' an Range (LXR). Seismic interpretation shows that the Chengzihe, Muling and Dongshan formations of the Hegang Basin thicken eastwards with westwards onlap, indicating that the LXR existed as a palaeo-uplift during that period, whereas the Houshigou Formation shows no thickness change, indicating that the LXR was possibly under water at this time. This is supported by results of detrital zircon analysis from the Hegang Basin in which the Chengzihe Formation is dominated by approximately $180 \mathrm{Ma}$ zircons, which can only be provided by the LXR, whereas the Houshigou Formation records no early Jurassic ages. This view is consistent with previous studies of the Songliao Basin for a provenance change between the Denglouku and Quantou formations. We conclude that the LXR was a highland during deposition of the Chengzihe, Muling and Dongshan formations but that it was under water when the Houshigou Formation was deposited. There was thus a connection between the Hegang and Songliao basins, which marks an eastwards migration of the depositional and extensional centre of the Songliao-Hegang basin system. This eastwards migration implies lithospheric extension driven by palaeo-Pacific roll-back.
\end{abstract}

Zircon grains in clastic sedimentary rocks are derived from the weathering of the surrounding source rocks, and are recognized as being highly resistant to chemical and physical weathering and other sedimentary processes (Jackson \& Sherman 1953). Detrital zircon analysis is widely recognized as a powerful tool for interpreting the provenance of sedimentary rocks (Drewery et al. 1987; Thomas 2011) because it has the ability to link sedimentary basins to their surrounding source regions (Riggs et al. 1996). Detrital zircon analysis can also be applied to infer maximum depositional ages of strata (Dickinson \& Gehrels 2009), to reconstruct supercontinent cycles (Li et al. 1995) and to reflect the tectonic settings of the basins in which they were deposited (Cawood et al. 2012).

The Hegang Basin is located to the east of the Lesser Xing'an Range (LXR), the Zhangguangcai Range (ZR) and the Songliao Basin, and lies within the Jiamusi Block to the west of the Sanjiang Basin, NE China (Fig. 1). It is $100 \mathrm{~km}$ long from north to south, and $28 \mathrm{~km}$ wide from east to west, with a total area of approximately $2800 \mathrm{~km}^{2}$. The Hegang Basin has been mined for coal since 1917 and contained China's largest opencast coal mine (before 2010) - the Lingbei Opencast Mine, which is now part of the Hegang National Mine Park. The coal types are mainly bituminous coal to anthracite. The strata of the Hegang Basin were previously considered to be Late Jurassic in age; however, a recent study based on palaeontology suggests that they were deposited in the Early Cretaceous (Sha et al. 2002).

The Songliao Basin is located between the LXR and ZR to the east, and the Great Xing'an Range to the west (Fig. 1). It is approximately $1000 \mathrm{~km}$ long from north to south, and $400 \mathrm{~km}$ wide from east to west, with a total area of approximately $350000 \mathrm{~km}^{2}$. The Songliao Basin contains oil- and gas-bearing non-marine sedimentary strata, and is one of the largest oil fields in China. It includes the Daqing oil field, which started production in 1959. The structure and sedimentology of the Songliao Basin have been well studied because of extensive oil and gas exploration and development (Wu et al. 2007; Feng et al. 2010b, 2011). Its structural evolution has been subdivided into three stages: synrift stage (the Huoshiling, 


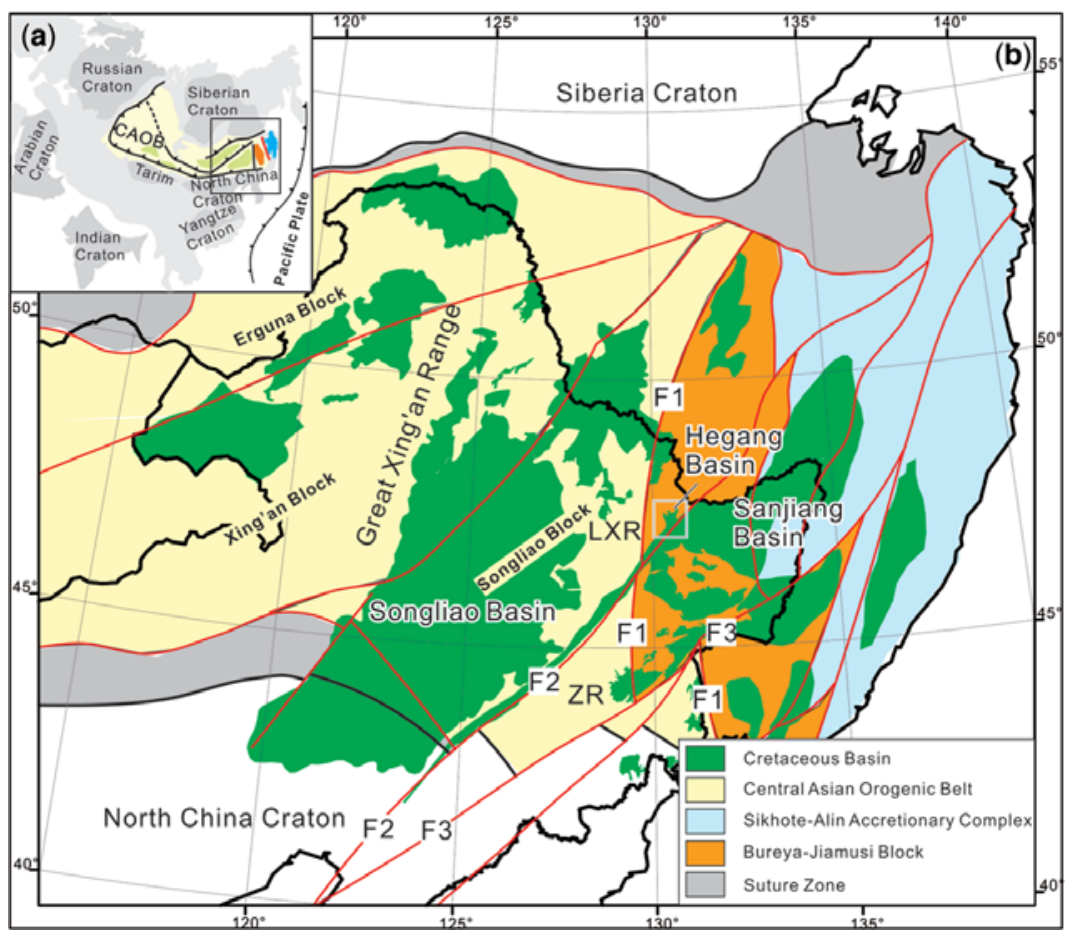

Fig. 1. (a) Location of the Central Asian Orogenic Belt (CAOB) and adjacent cratons. (b) Basin distribution in NE China and adjacent areas (after Zhou et al. 2009; Sorokin et al. 2010; Wu et al. 2011): F1, Mudanjiang Fault; F2, Yi-Shu Fault; F3, Dun-Mi Fault; LXR, Lesser Xing'an Range; ZR, Zhangguangcai Range.

Shahezi, Yingcheng and Denglouku formations) with asthenospheric upwelling and crustal extension; post-rift stage (the Quantou, Qingshankou, Yaojia and Nenjiang formations) with lithosphere cooling and subsidence; and the structural inversion stage (the Sifangtai, Mingshui, Yi'an, Da'an and Taikang formations) with compression and folding (Ren et al. 2002; Feng et al. 2010a).

Along the present eastern boundary of the Songliao Basin, most of the post-rift strata are deep lake facies (Zhang \& Bao 2009; Feng et al. 2010a, 2013; Gao et al. 2010; Xi et al. 2011; Wang et al. 2013). This poses some important scientific questions.

- Where was the original eastern boundary of the Songliao Basin in the post-rift period?

- Did the Songliao Basin ever spread east over the LXR?

- What is the relationship between the Songliao and Hegang basins?

In this study, we report a sensitive high-resolution ion microprobe (SHRIMP) zircon $\mathrm{U}-\mathrm{Pb}$ age of a tuff from the Houshigou Formation, and detrital zircon ages for the Chengzihe and Houshigou formations of the Hegang Basin. In light of these results, we review the distribution of Late TriassicEarly Jurassic igneous rocks in NE China and the detrital zircon geochronology of the Songliao Basin in order to test for any similarities with the Hegang Basin. This study will help in understanding sedimentary basin development and the tectonic evolution of East Asia. It is also relevant to the timing of changes in tectonic regime, associated with the advance and retreat of the palaeo-Pacific Plate, which has dominated the architecture of eastern China since the early Mesozoic.

\section{Geological setting}

NE China and adjacent regions in Far East Russia are made up of several massifs and terranes that are located between the Siberia and North China cratons (Fig. 1), including the Erguna, Xing'an, Songliao, Bureya and Jiamusi blocks, and the Sikhote-Alin accretionary complex (Wu et al. 2005; Yu et al. 2008; Kotov et al. 2009; Sorokin et al. 2010; Zhou et al. 2011a). The Erguna, Xing' an and Songliao blocks are considered to be the eastern part of the Central Asian Orogenic Belt (CAOB) that amalgamated in the Palaeozoic (Xiao et al. 2009, 2010), whereas the Jiamusi block and Sikhote-Alin accretionary complex are early Mesozoic circum-Pacific accreted terranes (Zhou et al. 2009; Wu et al. 2011). The amalgamated 


\section{EVOLUTION OF CRETACEOUS BASINS, NE CHINA}

Erguna, Xing'an and Songliao blocks collided with the North China Craton in the Permian (Xiao et al. 2003), and with the Siberia Craton in the late Palaeozoic-early Mesozoic (Kravchinsky et al. 2002). Final collision with the Jiamusi Block occurred in the early Mesozoic (Zhou et al. 2009), forming the unified Jiamusi-Mongolia block (Wang et al. 2011). The ocean separating the Jiamusi-Mongolia block from the Siberia Craton closed completely in the early Early Cretaceous (Cogne et al. 2005).

The Songliao Block is overlain by MesozoicCenozoic strata of the Songliao Basin. Most of the basement beneath the Songliao Basin is composed of Palaeozoic-Mesozoic granitoids and Palaeozoic strata (Wu et al. 2000, 2001; Gao et al. 2007; Pei et al. 2007; Yu et al. 2008; Zhou et al. 2012), with minor Proterozoic granitoids (Wang et al. 2006). In the eastern part of the Songliao Block, the basement was uplifted and forms the LXR and ZR, which also contain Palaeozoic-Mesozoic granitoids and Palaeozoic strata (Meng et al. 2010, 2011; Wang et al. 2012a, b).

The Jiamusi Block has a pre-Mesozoic basement that is composed mainly of the Mashan Complex, the Heilongjiang Complex and Permian granite

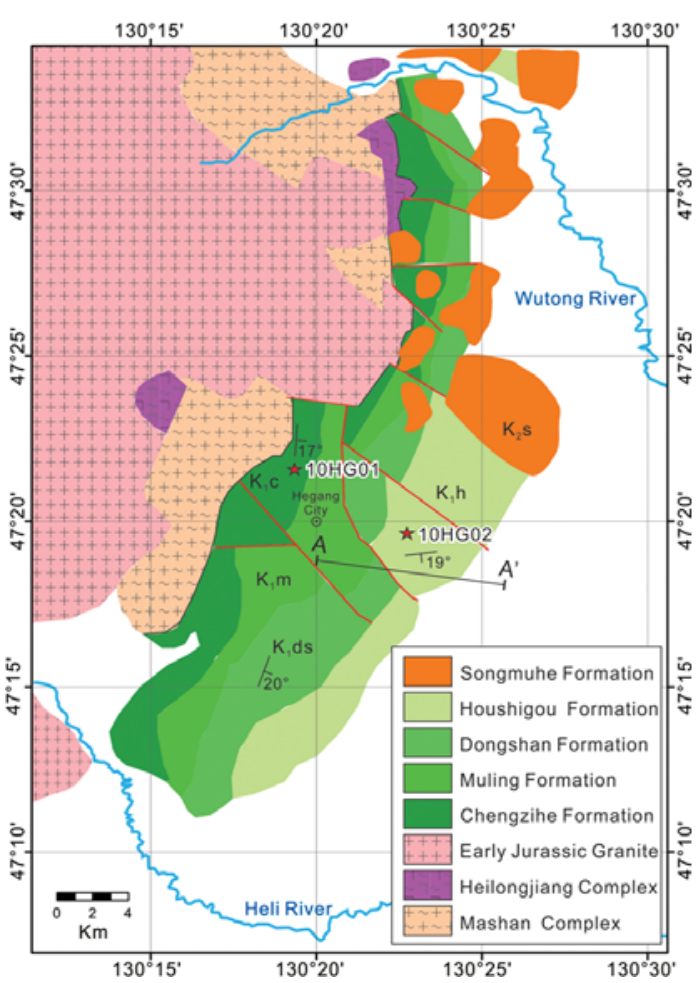

Fig. 2. Simplified geological map of the Hegang Basin, based on the Hegang and Jiamusi 1:200 000 geological maps.
(Wu et al. 2011). The Mashan Complex makes up the main part of the Jiamusi Block and consists of khondalitic rocks with a metamorphic age of $500 \mathrm{Ma}$ (Wilde et al. 1999, 2000, 2003). The Heilongjiang Complex is distributed in the western part of the Jiamusi Block, and consists of ultramafic rocks, blueschist-facies pillow basalts, carbonates and mylonitic mica schists, which are considered to represent a mélange along the suture between the Jiamusi and Songliao blocks (Wu et al. 2007; Zhou et al. 2009).

\section{Stratigraphy and structure of the Hegang Basin}

\section{Stratigraphy}

The basement of the Hegang Basin is composed of the Mashan and Heilongjiang complexes and Jurassic granites (Fig. 2). The basin strata are named, from bottom to top, the Chengzihe, Muling, Dongshan, Houshigou and Songmuhe formations (Figs $2 \& 3)$. The Chengzihe, Muling and Dongshan formations constitute the Jixi Group (Gu et al. 1997;

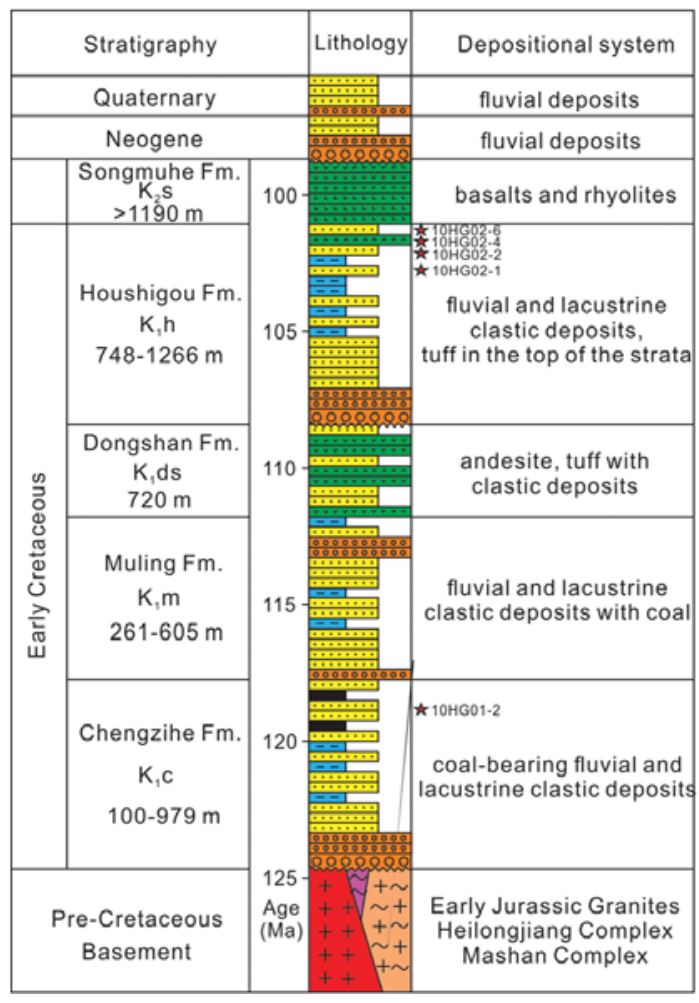

Fig. 3. Stratigraphic column of the Hegang Basin showing the relative positions of samples, based on the Hegang and Jiamusi 1:200 000 geological maps; the stars show the relative location of samples used in this study. 


\section{SUN ET AL.}

Li et al. 2006), and their contacts are conformable (Sha et al. 2002, 2003, 2009; Sha 2007).

The Chengzihe Formation $\left(\mathrm{K}_{1} \mathrm{c}\right)$ ranges in thickness from 100 to $979 \mathrm{~m}$. The lower part consists of fluvial facies with medium- to coarse-grained sandstone, conglomerate, siltstone, mudstone and tuff. The middle part consists of fluvial and lacustrine facies fine- to medium-grained sandstone, siltstone and mudstone, with minor coarse sandstone and conglomerate. The middle unit contains 36 coal seams of mineable quality and is also rich in plant fossils. The upper part of the Chengzihe Formation consists of fluvial facies, fine-grained sandstone and siltstone, with mudstone and tuff.

The Muling Formation $\left(\mathrm{K}_{1} \mathrm{~m}\right)$ conformably overlies the Chengzihe Formation, with a thickness ranging from 261 to $605 \mathrm{~m}$. It consists of thick yellowish-brown conglomerate, grey sandstone, and dark grey siltstone and mudstone, with thin layers of tuff, indicating fluvial to deltaic facies with occasional distal volcanism.

The Dongshan Formation $\left(\mathrm{K}_{1} \mathrm{ds}\right)$ consists of grey-green andesite, andesitic agglomerate, volcanic breccia and tuff, with some siltstone and sandstone. Its total thickness is $720 \mathrm{~m}$.

The Houshigou Formation $\left(\mathrm{K}_{1} \mathrm{~h}\right)$ overlies the Dongshan Formation with a minor angular unconformity, and it ranges in thickness from 748 to $1266 \mathrm{~m}$. The lower part consists of fluvial facies conglomerate and yellow sandstone. The clasts in the conglomerate consist mainly of andesite, gneiss and granite. The upper part of the Houshigou Formation consists of lacustrine facies black, finegrained sandstone, siltstone and mudstone, with a tuff interlayer at the top.

The Songmuhe Formation $\left(\mathrm{K}_{2} \mathrm{~s}\right)$ consists of volcanic rocks with thickness of $1087 \mathrm{~m}$. It has two members. The lower part, the Xigemu Member, consists of andesite, basalt and tuff, with a total thickness of $600 \mathrm{~m}$. The upper part, the Aoqi Member, consists of rhyolite, tuff and volcanic breccia, with a total thickness of $487 \mathrm{~m}$.

\section{Structure}

The Early Cretaceous Hegang Basin was possibly part of the Sanjiang Basin (Fig. 1), as suggested by Zhang et al. (2012). However, the structural prototype of the Hegang Basin was difficult to rebuild because it is separated from the Sanjiang Basin by the Cenozoic Yishu Fault (F2, Fig. 1) and was also destroyed by a westwards Late CretaceousCenozoic thrust fault (Huang et al. 2003; Sun et al. 2006), as also shown in the seismic profile (Fig. 4). Nevertheless, the seismic profile still provides important information that helps in the understanding of the provenance of the Hegang Basin. In general, the Early Cretaceous strata dip eastwards at approximately $15^{\circ}$, showing a monoclinal structure. In detail, the Chengzihe, Muling and Dongshan formations thicken eastwards with westwards onlap on to the early Mesozoic granite basement, which is the main component of LXR, indicating that the LXR existed as a palaeo-uplift during that period, while the Houshigou Formation has no change in thickness, indicating that the LXR was possibly under water at this time. Hence, the structure of the Hegang Basin implies a possible provenance change from the Chengzihe Formation to the Houshigou Formation.

\section{Sample locations and petrology}

Two sections were chosen for this investigation, both located close to Hegang City in eastern Heilongjiang Province, in order to sample and compare the rocks from the Chengzihe and Houshigou formations, which are located beneath and above the major unconformity surface, respectively.

Section 10HG01 (Fig. 5) is in the Lingbei Coal Mine, where sandstone sample 10HG01-2 was collected $\left(47^{\circ} 21^{\prime} 30^{\prime \prime} \mathrm{N}, 130^{\circ} 19^{\prime} 0^{\prime \prime} \mathrm{E}\right)$ from the middle part of the Chengzihe Formation. This section is rich in plant fossils characterized by Filicopsida, and several species of Ginkgopsida and Coniferopsida (Fig. 5). Sun \& Dilcher (2002) and Liu (2006) gave a statistical analysis of $40 \%$ Filicophytina, 20\% Bennettitales, 10\% Ginkgo, 10\% Coniferopsida and $10 \%$ early angiosperms. These authors correlate this assemblage with the Barremian Stage. It further indicates that the climate of the Jiamusi area at this time was warm and humid, possibly even subtropical.

Section 10HG02 (Fig. 6) is at a location $\left(47^{\circ} 19^{\prime} 39^{\prime \prime} \mathrm{N}, 130^{\circ} 22^{\prime} 44^{\prime \prime} \mathrm{E}\right)$ near fishponds outside of Wugongli Village, on the western side of the Haluo Highway. Samples 10HG02-1, 10HG02-2, $10 \mathrm{HG} 02-4$ and 10HG02-6 were collected from the upper part of the Houghigou Formation. Sample $10 \mathrm{HG} 01-2$ is a grey-white coarse-grained sandstone. The grains are $0.3-1 \mathrm{~mm}$ in diameter, subangular and poorly sorted, and are composed of $50 \%$ quartz, $30 \%$ feldspar and $20 \%$ lithic fragments. The accessory minerals are mainly zircon, pyrite and siderite. Samples 10HG02-1 and 10HG02-2 are yellow-dark yellow fine-grained sandstone. The grains are mostly $0.1-0.3 \mathrm{~mm}$ in diameter, angular and moderately well sorted, and composed approximately of $60 \%$ quartz, $30 \%$ feldspar and $10 \%$ lithic fragments. The accessory minerals are mainly garnet and titanite. Sample 10HG02-4 is a white rhyolitic tuff with crystal and glass fragments. Sample 10HG02-6 is a yellow coarse-grained sandstone, composed of $70 \%$ quartz, $20 \%$ feldspar and $5 \%$ lithic fragments. 
EVOLUTION OF CRETACEOUS BASINS, NE CHINA
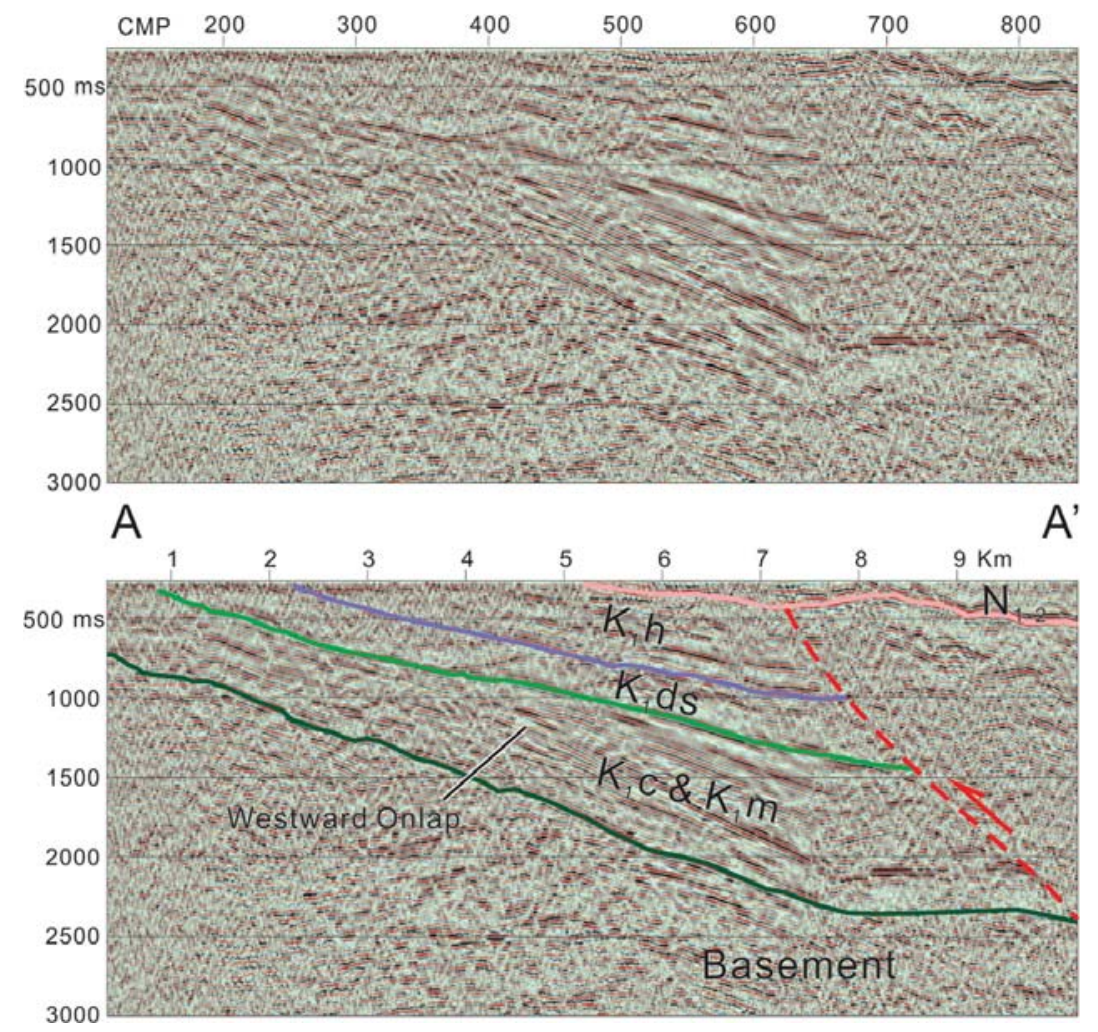

Fig. 4. Seismic profile across the Hegang Basin with an interpretation showing that the Chengzihe and Muling formations thicken from west to east with a westwards onlap on to the basement. Seismic data were provided by PetroChina.

\section{Analytical methods}

Approximately $3 \mathrm{~kg}$ samples were collected from each site for zircon separation. Zircon crystals were extracted by crushing, and by heavy liquid and magnetic separation at the Langfang Geological Services Corporation, Hebei Province, China. More than 2000 zircon grains were extracted from each sample. Zircons from the tuff sample HG02-4, taken to the Beijing SHRIMP Centre, were mounted

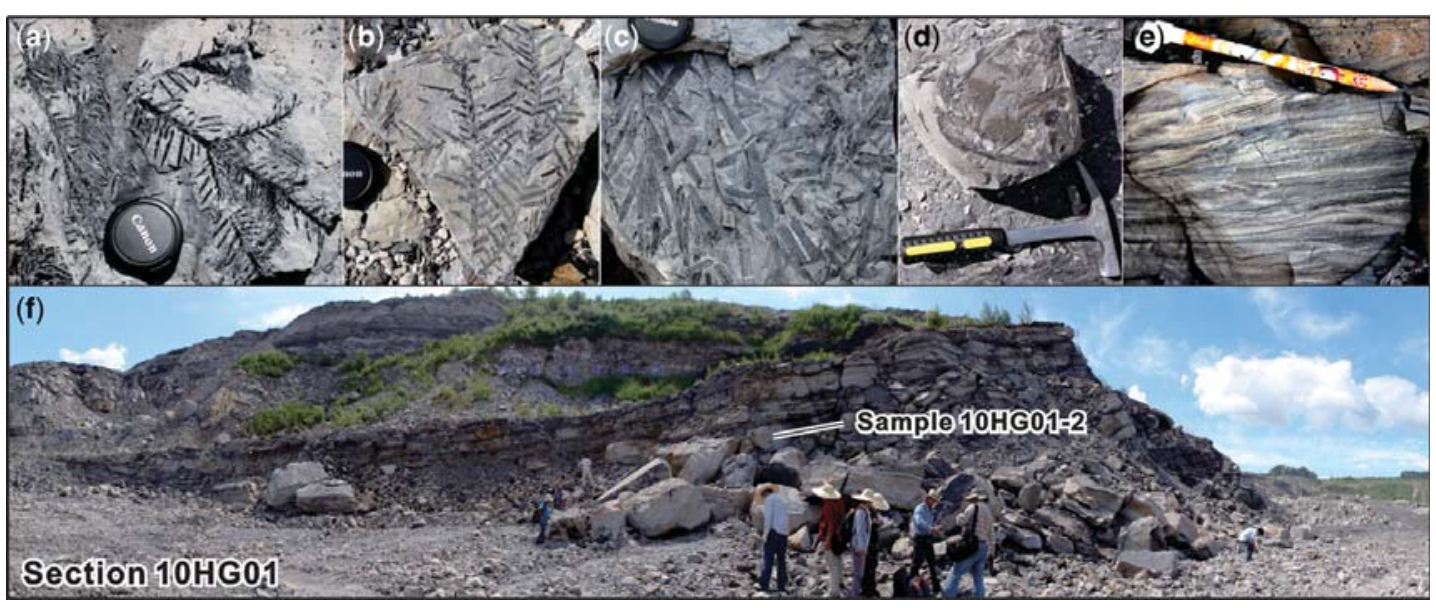

Fig. 5. Photograph of section 10HG01, Chengzihe Formation: (a) \& (b) Filicophytina; (c) Bennettitales; (d) Ginkgo leaf; (e) laminae in siltstone; and (f) photograph showing the sample location. 

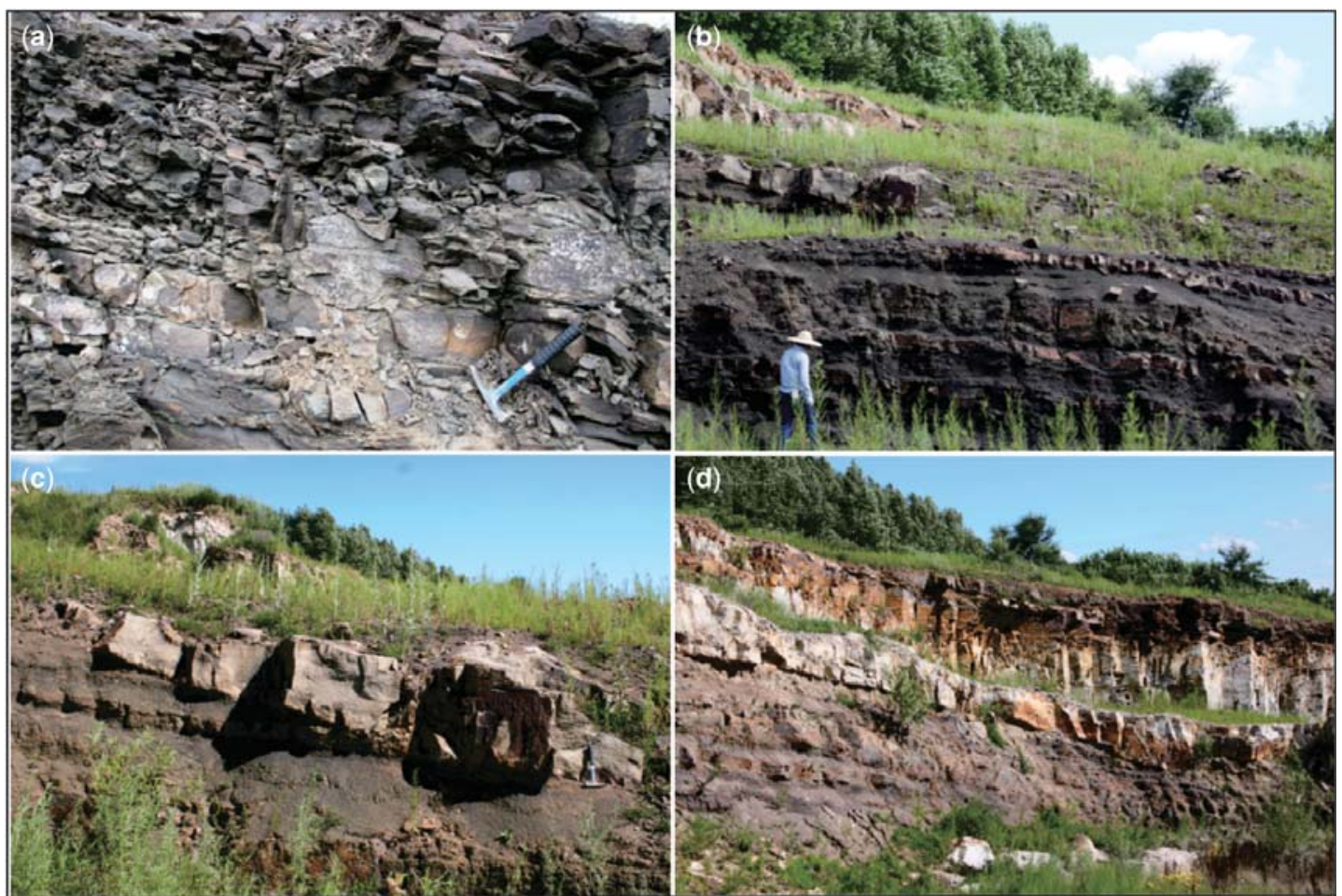

(e)

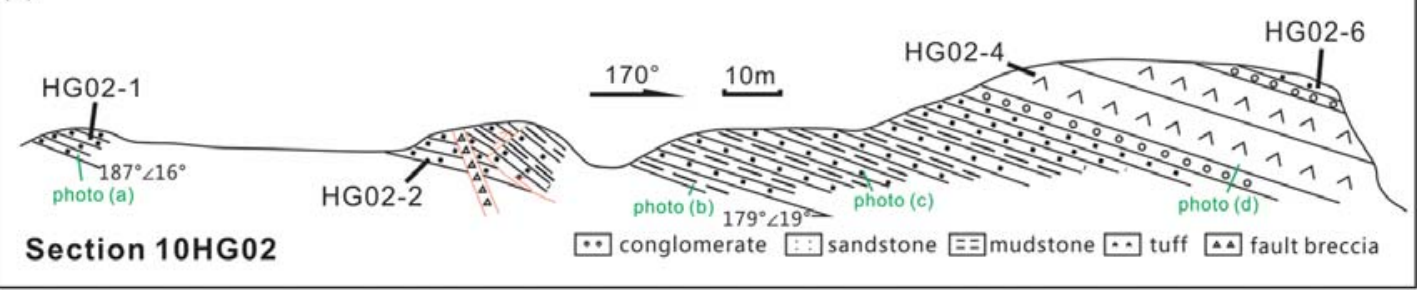

Fig. 6. Photograph of section 10HG02, Houshigou Formation: (a) black siltstone; (b) thin layered grey-yellow sandstone with a dark mudstone interbed; (c) small channel sandbody; (d) white tuff; and (e) section sketch, showing the sample sites.

along with the TEMORA standard (Black et al. 2003) and polished to reveal the grain centres. Zircons from the sandstones, taken to the Second Institute of Oceanography of State Oceanic Administration of China in Hangzhou, were also mounted and polished. Cathodoluminescence (CL) images were taken using a Philips XL30 scanning electron microscope at Curtin University, Perth following $\mathrm{U}-\mathrm{Pb}$ analysis. Most zircons from each sample are transparent, pale yellow and euhedral prismatic, and are typically magmatic with concentric oscillatory zonation evident in the CL images (Fig. 7).

SHRIMP $\mathrm{U}-\mathrm{Pb}$ dating was performed using a SHRIMP II ion microprobe at the Beijing SHRIMP Centre following standard procedures (Wan et al. 2005). The mass resolution was approximately 5000 at $1 \%$ peak height. The spot size of the ion beam was
25-30 $\mu \mathrm{m}$, and five scans through the mass range were used for data collection. Standard SL13 (572 Ma, U = $238 \mathrm{ppm}$ ) was used for U concentration and age calibration, and TEMORA (417 Ma) (Black et al. 2003) was used to monitor analytical conditions. Ages and Concordia diagrams were calculated using the programs Squid 1.03 (Ludwig 2001) and Isoplot 3.0 (Ludwig 2003).

Laser ablation inductively coupled plasma mass spectrometry (LA-ICP-MS) $\mathrm{U}-\mathrm{Pb}$ dating was carried out at the State Key Laboratory of Mineral Deposits Research at Nanjing University. The LAICP-MS consisted of an Agilent $7500 \mathrm{~s}$ ICP-MS attached to a Merchantek/NWR $213 \mathrm{~nm}$ laser ablation system. The diameter of the analysis spot was $25 \mu \mathrm{m}$. The repetition rate and power was $5 \mathrm{~Hz}$ and $68 \%$, respectively. About 100 grains of each 

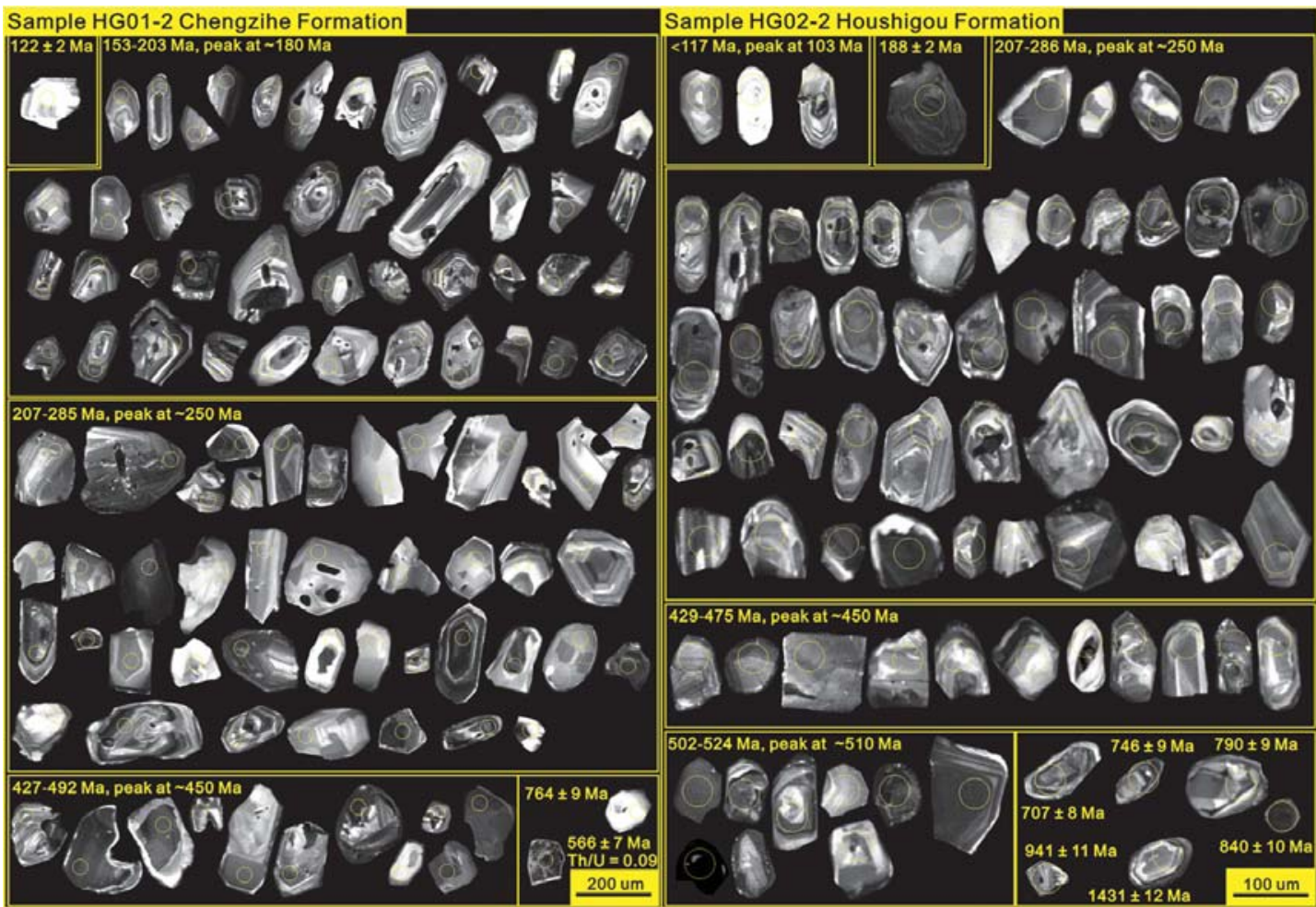

Fig. 7. CL images for representative zircons from the sandstones of the Chengzihe and Houshigou formations.

sandstone sample were analysed. $\mathrm{U}-\mathrm{Pb}$ fractionation was corrected using standard zircon GJ $\left({ }^{207} \mathrm{~Pb} /{ }^{206} \mathrm{~Pb}\right.$ age of $608.5 \pm 1.5 \mathrm{Ma}$ : Jackson et al. 2004), and reproducibility was controlled using a standard zircon Mud Tank (MT) $\left({ }^{207} \mathrm{~Pb} /{ }^{206} \mathrm{~Pb}\right.$ age of $732 \pm 5$ Ma: Black \& Gulson 1978). The analytical data were processed using Glitter 4.4 software. Because ${ }^{204} \mathrm{~Pb}$ could not be measured owing to a low signal and interference from ${ }^{204} \mathrm{Hg}$ in the gas supply, the common lead correction was carried out using the Excel program ComPbcorr\#315G (Andersen 2002). The Concordia diagrams and histograms were plotted using Isoplot 3.0 (Ludwig 2003). In this investigation, zircons younger than $1.0 \mathrm{Ga}$ were calculated using the ${ }^{206} \mathrm{~Pb} /{ }^{238} \mathrm{U}$ age, whereas older ones were calculated using the ${ }^{207} \mathrm{~Pb} /{ }^{206} \mathrm{~Pb}$ age.

\section{Analytical results}

\section{Sample 10HG01-2}

Sample 10HG01-2, collected from the Chengzihe Formation, contained zircon grains $40-400 \mu \mathrm{m}$ long and a total of 109 randomly selected grains were analysed (Table 1). Two grains were excluded from the calculations because of discordance. The remaining 107 grains were concordant at the $90 \%$ confidence level. The ${ }^{206} \mathrm{~Pb} /{ }^{238} \mathrm{U}$ ages fall mainly into three groups (Fig. 8a): 203-153 Ma (44\%), 285-207 Ma (41\%) and 492-427 Ma (9\%), with peaks at approximately 180, 250 and $450 \mathrm{Ma}$ (Fig. 8b). The age of $122 \pm 2$ Ma for the youngest grain defines the maximum depositional age of the Chengzihe Formation.

\section{Sample 10HG02-1}

Sample 10HG02-1 was collected from the Houshigou Formation. Zircon grains were 40-200 $\mu \mathrm{m}$ long and a total of 84 randomly selected grains were analysed (Table 2). One grain was excluded from the calculations because of the large error. The remaining 83 grains gave concordant ages at the $90 \%$ confidence level. The ${ }^{206} \mathrm{~Pb} /{ }^{238} \mathrm{U}$ ages of Phanerozoic zircons mainly fall into three populations (Fig. 8c): 283-223 Ma (39\%), 484-427 Ma $(14 \%)$ and $522-501 \mathrm{Ma}(14 \%)$, with peaks at approximately 250, 450 and $510 \mathrm{Ma}$, respectively (Fig. 8d). The youngest zircon has an age of $104 \pm 2 \mathrm{Ma}$, thus constraining the maximum age of deposition. There is also $12 \%$ of Precambrian zircons in the population, with ${ }^{207} \mathrm{~Pb} /{ }^{206} \mathrm{~Pb}$ ages ranging from 1.4 to $0.6 \mathrm{Ga}$. 
M. SUN ET AL.

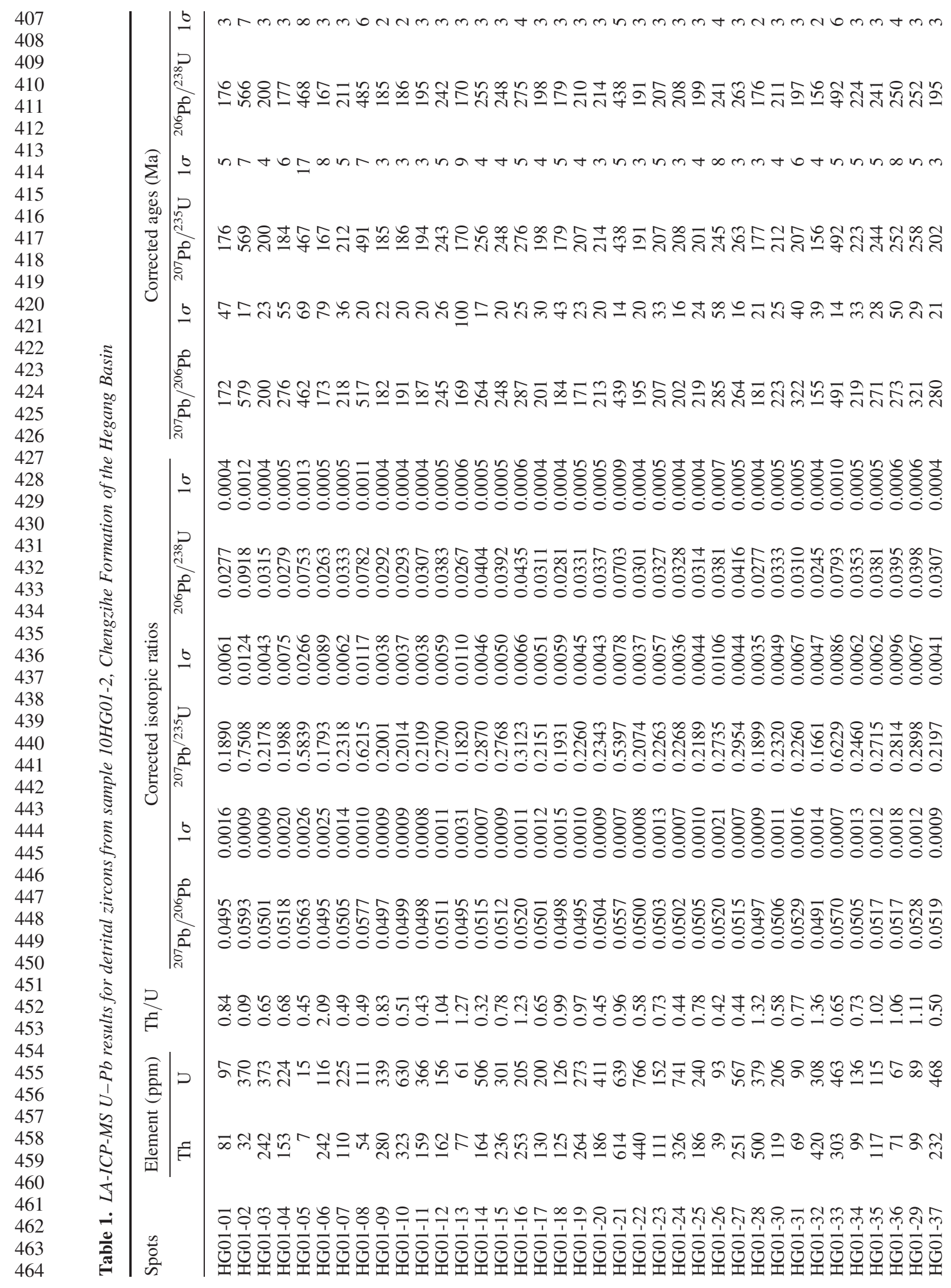




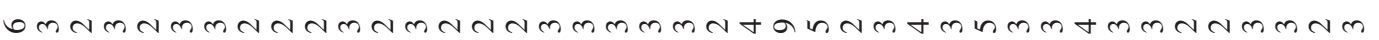

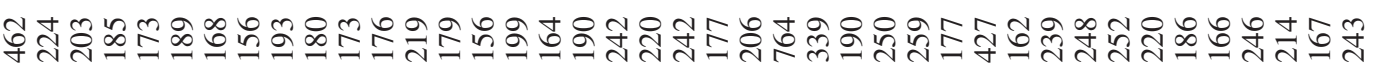

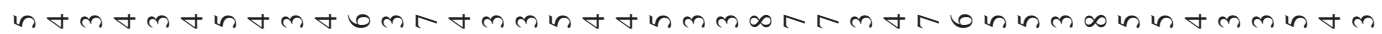

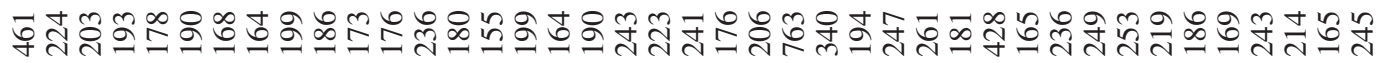

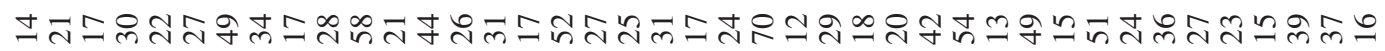

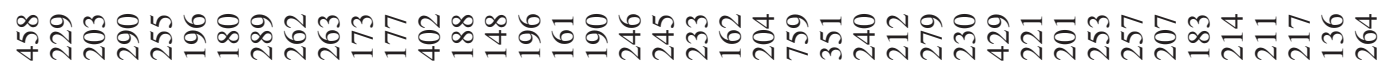

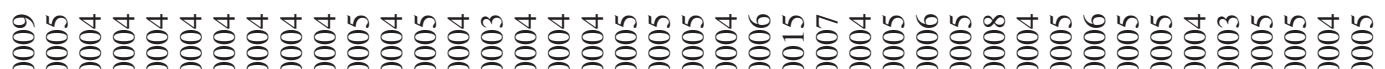

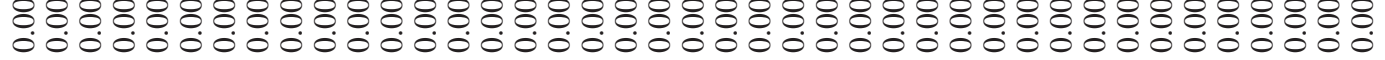

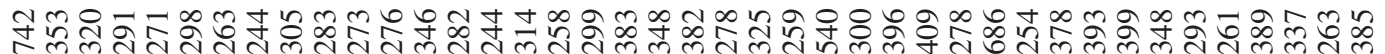

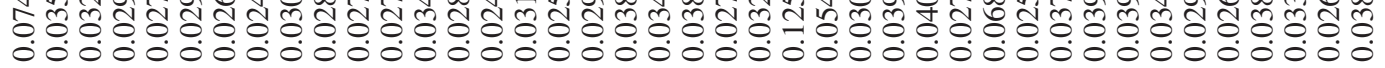

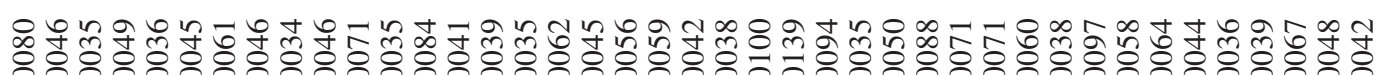

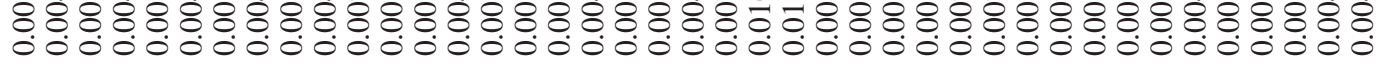

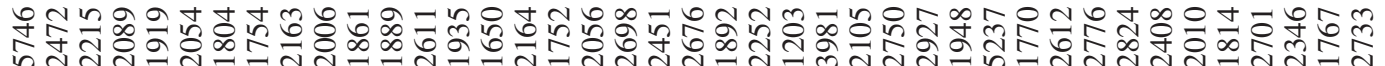

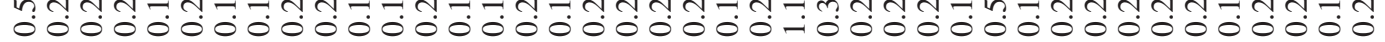

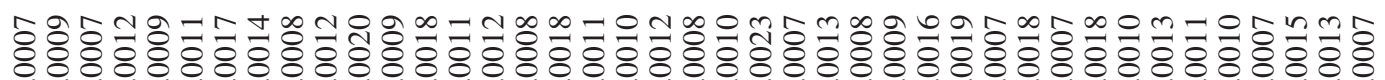

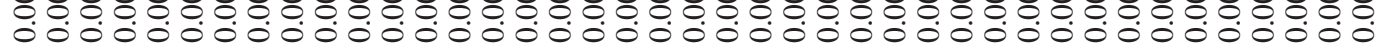

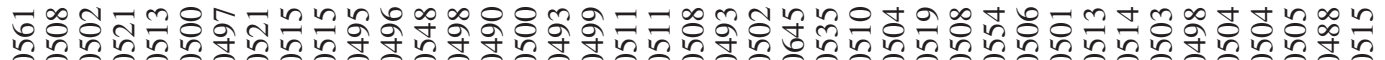

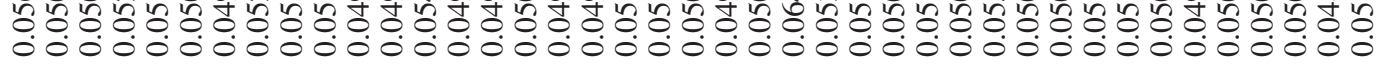

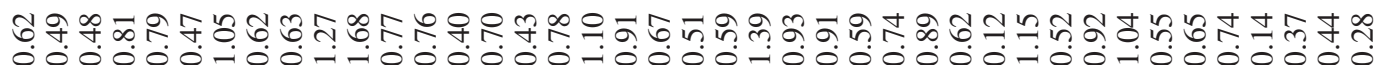

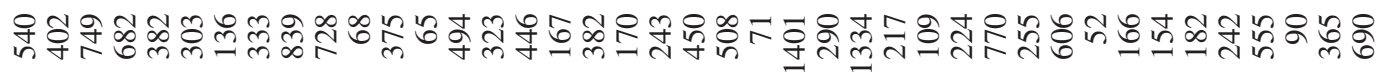

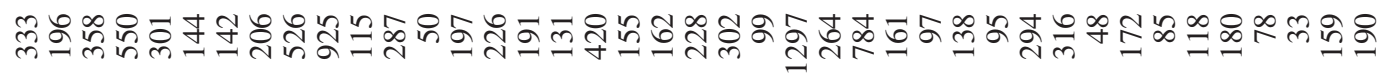

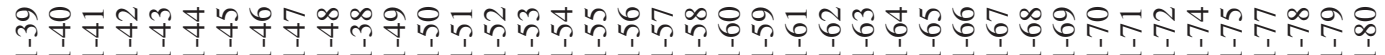

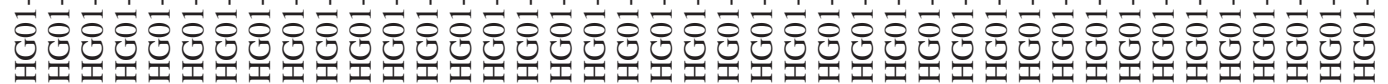


M. SUN ET AL.

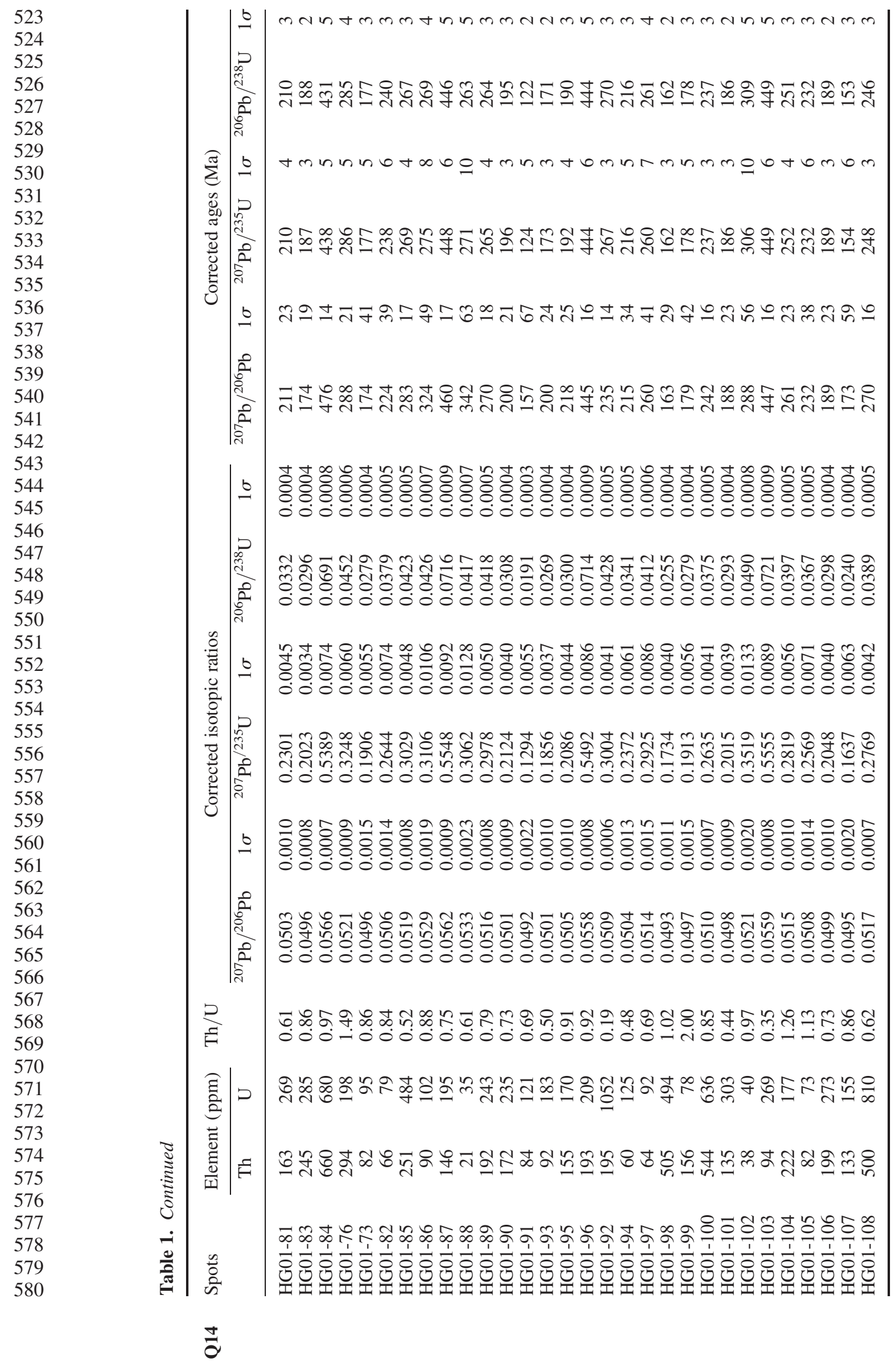


(a)

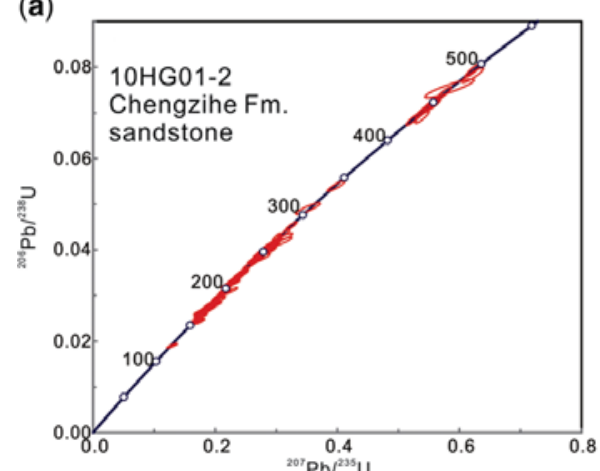

(b)

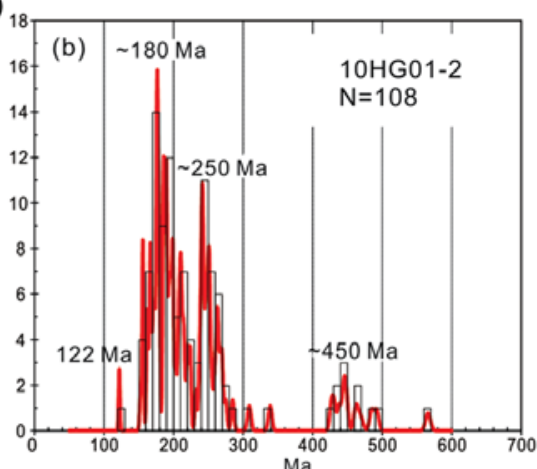

(d)
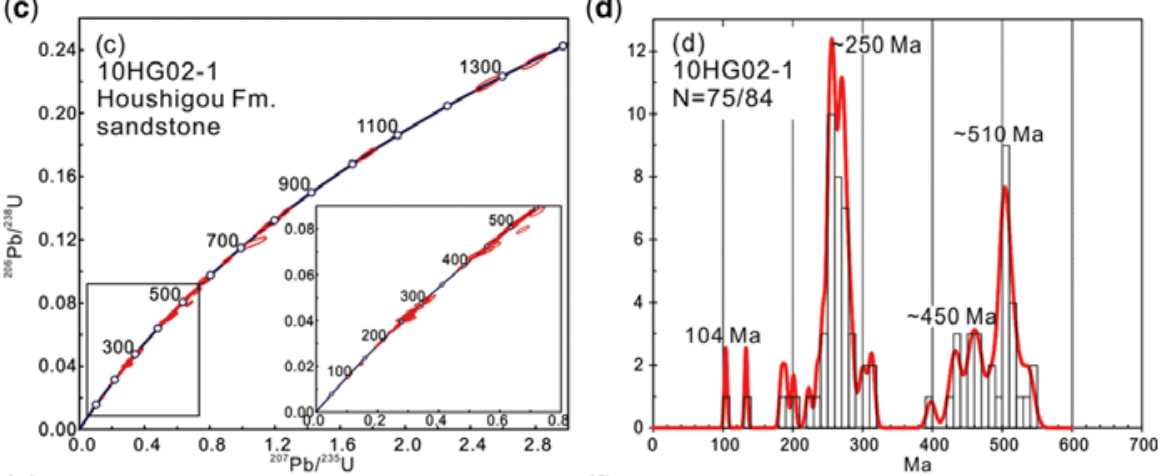

(e)
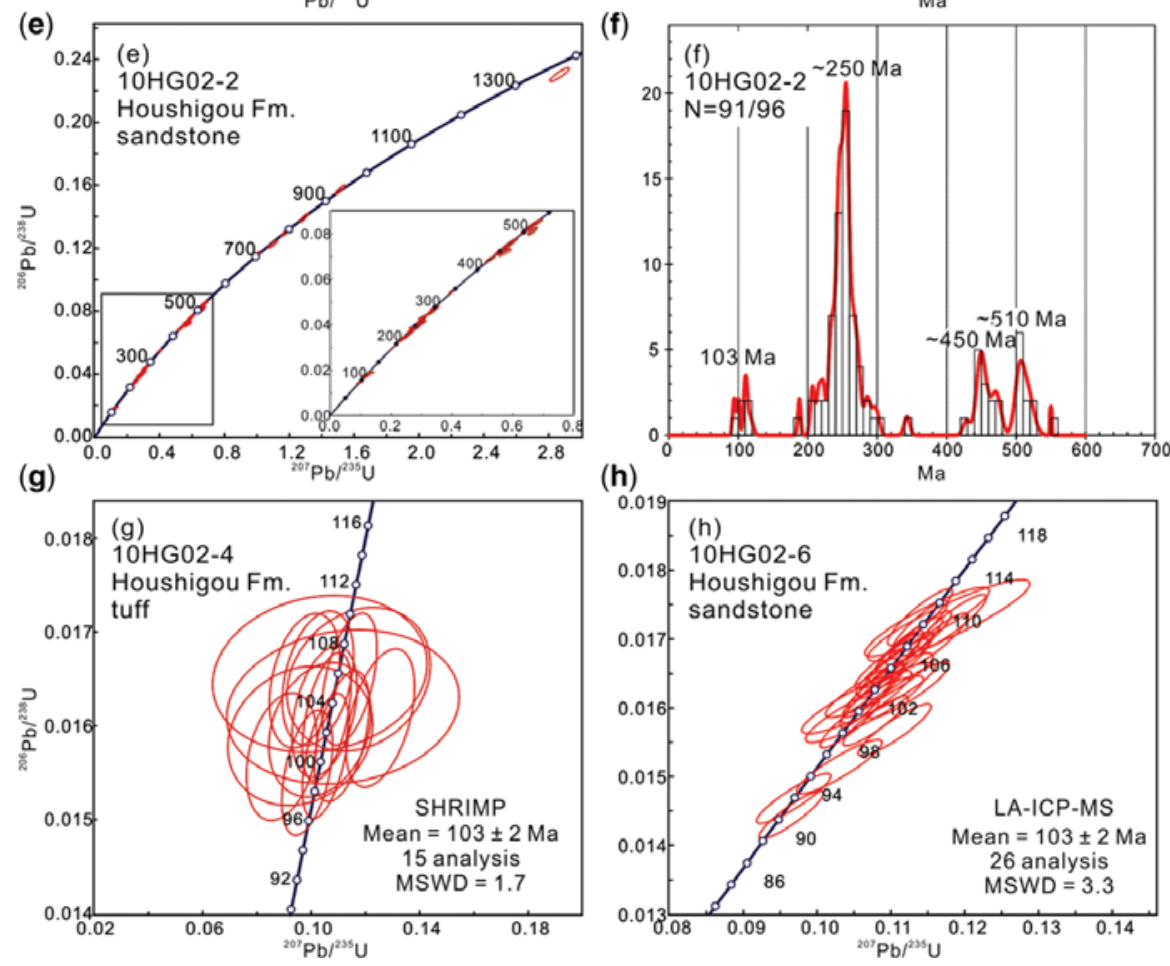

Fig. 8. (a) LA-ICP-MS U-Pb zircon Concordia diagram and (b) probability diagram of sandstone sample 10HG01-2 from the Chengzihe Formation. (c) LA-ICP-MS U-Pb zircon Concordia diagram and (d) probability diagram of sandstone sample 10HG02-1 from the Houshigou Formation. (e) LA-ICP-MS U-Pb zircon Concordia diagram and (f) probability diagram of sandstone sample 10HG02-2 from the Houshigou Formation. (g) SHRIMP zircon Concordia diagram for tuff sample 10HG02-4 from the Houshigou Formation. (h) LA-ICP-MS U-Pb Concordia diagram of sandstone sample 10HG02-6 from the Houshigou Formation. MSWD, mean standard weight of deviation. 
M. SUN ET AL.

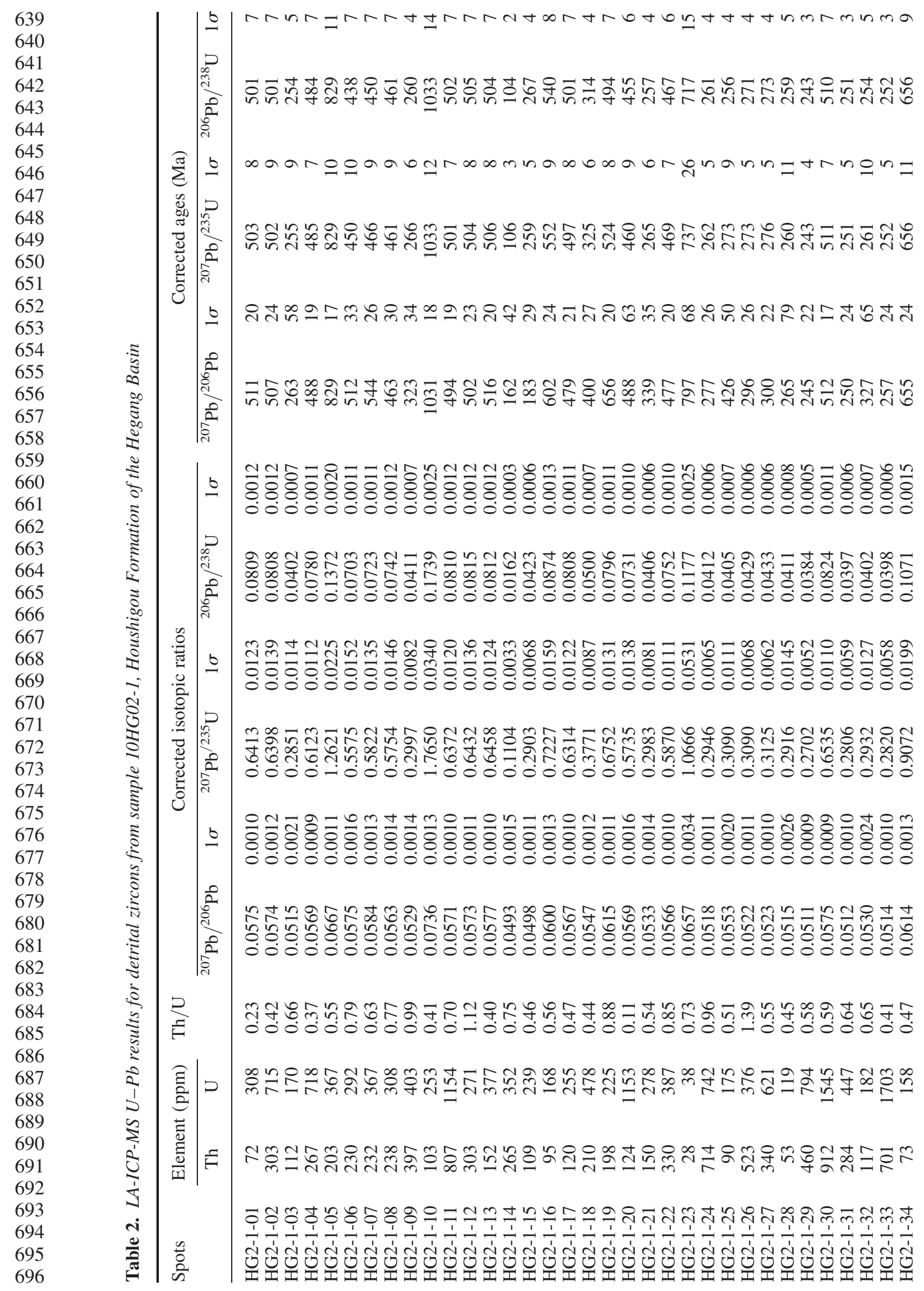


EVOLUTION OF CRETACEOUS BASINS, NE CHINA

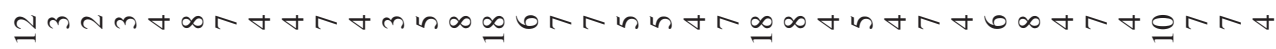

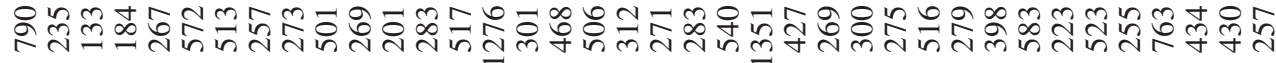

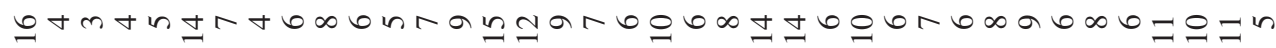

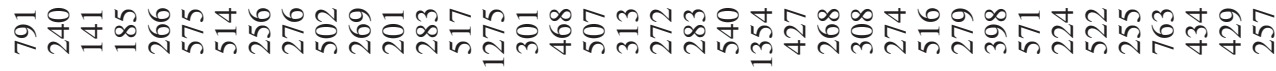

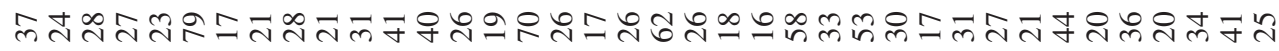

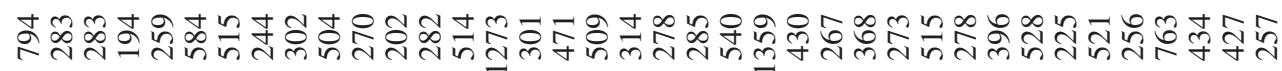

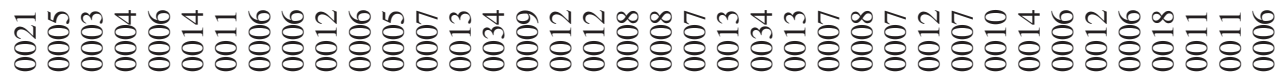

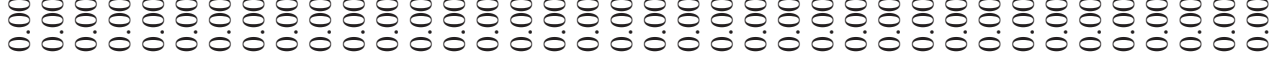

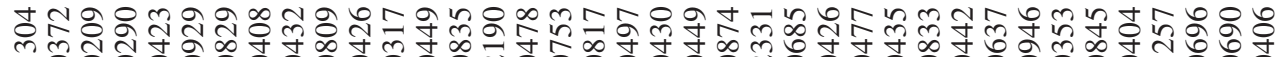

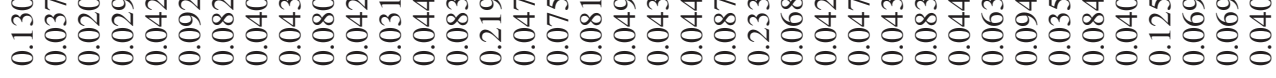

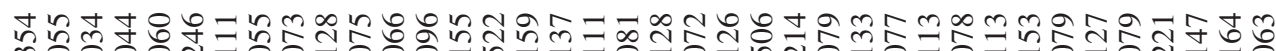

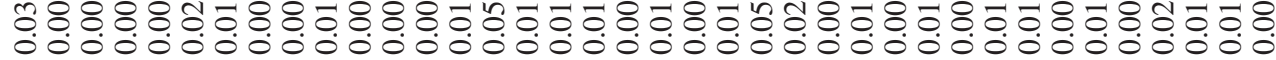

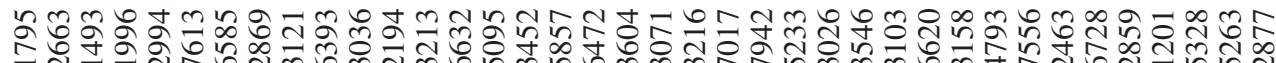
=

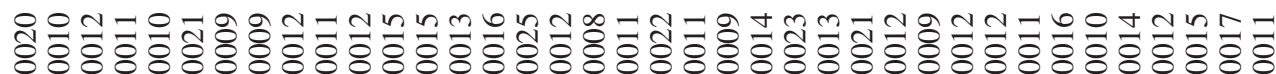
o.

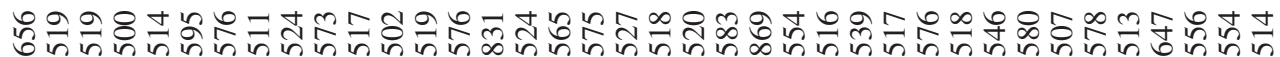


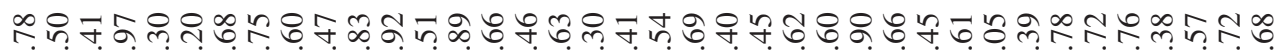
$0000000000000000000000000-000000000000$

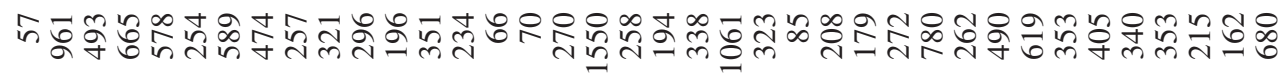

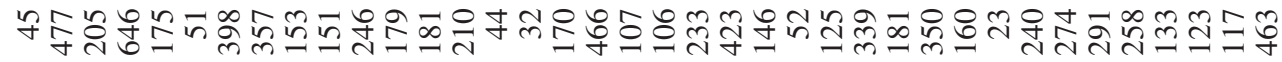

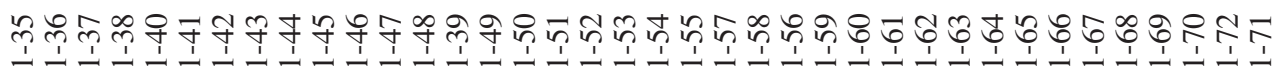

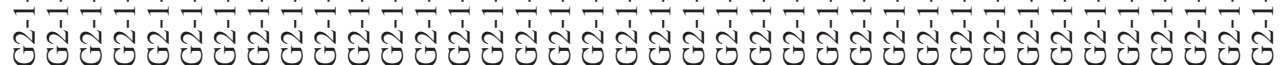

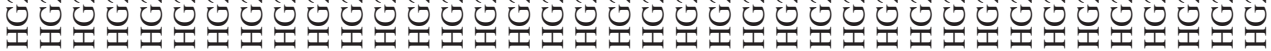


M. SUN ET AL.

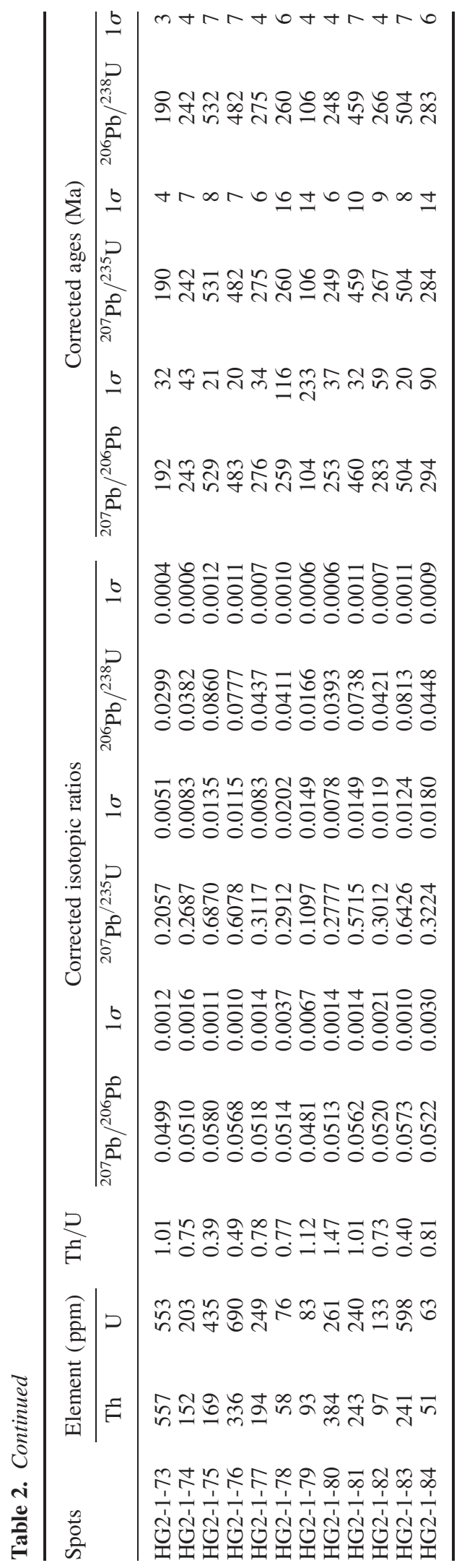




\section{Sample 10HG02-2}

Sample 10HG02-2 was also collected from the Houshigou Formation. Zircon grains were 40$200 \mu \mathrm{m}$ long and a total of 96 randomly selected grains were analysed (Table 3); all grains were concordant at the $90 \%$ confidence level. The ${ }^{206} \mathrm{~Pb} /$ ${ }^{238} \mathrm{U}$ ages mainly fall into three populations (Fig. 8e): 286-207 Ma (60\%), 475-429 Ma (14\%) and 524-502 Ma (10\%), with peaks at approximately 250, 450 and $510 \mathrm{Ma}$, respectively (Fig. 8f), identical to the populations in sample 10HG02-1. The youngest zircon has a ${ }^{206} \mathrm{~Pb} /{ }^{238} \mathrm{U}$ age of $94 \pm$ 2 Ma. However, sample 10HG02-2 cannot be younger than sample 10HG02-4 according to the field relationships. Since there is only one grain younger than $100 \mathrm{Ma}$, the mean age of $103 \pm 2 \mathrm{Ma}$ given by five Cretaceous zircons probably represents the best estimate of the age of the stratum. There are also six Precambrian zircons with ${ }^{207} \mathrm{~Pb} /{ }^{206} \mathrm{~Pb}$ ages ranging from 1.4 to $0.7 \mathrm{Ga}$.

\section{Sample 10HG02-4}

Sample 10HG02-4 was collected from the tuff layer in the upper part of Houshigou Formation, stratigraphically above samples 10HG02-1 and 10HG02-2. Zircon grains were mostly $70 \mu \mathrm{m}$ long, with 2:1 aspect ratios. Seventeen zircon grains were analysed by SHRIMP (Table 4). The measured $\mathrm{U}$ and $\mathrm{Th}$ concentrations varied from 195 to $1119 \mathrm{ppm}$ and from 89 to $645 \mathrm{ppm}$, respectively. The $\mathrm{Th} / \mathrm{U}$ ratio ranges from 0.40 to 0.66 . One grain was excluded from the calculation because it is considered to be an inherited zircon with an age of $256 \pm 7$ Ma. The remaining 16 analyses give a weighted mean age of $103 \pm 2 \mathrm{Ma}$ (mean square weighted deviation $(\mathrm{MSWD})=1.7$ ) (Fig. $8 \mathrm{~g}$ ), recording the eruption time of the tuff. This is coeval, within error, of the best estimate of the age of deposition of the underlying Houshigou Formation, suggesting rapid deposition within the Hegang Basin.

\section{Sample 10HG02-6}

This sample was collected from a sandstone unit above the tuff layer in the upper part of the Houshigou Formation. Zircon grains were mostly $70 \mu \mathrm{m}$ long, with 2:1 aspect ratios. Thirty-six zircon grains were analysed using LA-ICP-MS (Table 5), and the $\mathrm{U}$ and $\mathrm{Th}$ concentrations varied from 111 to $1330 \mathrm{ppm}$ and from 83 to $1240 \mathrm{ppm}$, respectively, with $\mathrm{Th} / \mathrm{U}$ ratios ranging from 0.52 to 1.72 . Twenty-six analyses (excluding five discordant grains and five inherited grains with ages of 117 , 185, 208, 270 and $516 \mathrm{Ma}$ ) give a weighted mean age of $103 \pm 2 \mathrm{Ma}(\mathrm{MSWD}=3.3$ ) (Fig. 8h), suggesting that most of the zircons were derived either from the tuff or from strata immediately underlying the tuff.

\section{Discussion}

\section{Detrital zircon provenance change in the Hegang Basin}

According to the data presented above, both the Chengzihe and Houshigou formations have provenance sources from terranes characterized by ages of around 250 and $450 \mathrm{Ma}$. However, the Chengzihe Formation is dominated by approximately $180 \mathrm{Ma}$ zircons, whereas the Houshigou Formation has no Late Triassic-Early Jurassic zircons but, instead, has zircons of around $510 \mathrm{Ma}$.

The approximately 250, 450 and $510 \mathrm{Ma}$ provenance was most probably derived from the Jiamusi Block to the east, which consists of both Late Permian granites and Pan-African granites and gneiss (Wilde et al. 1997; Zhou et al. 2009, 2010, 2011a; W uet al. 2011).

The provenance of $180 \mathrm{Ma}$ was possibly from the LXR to the west, since this is a dominant age in this region (Wu et al. 2011). The LXR consists dominantly of Early Jurassic bimodal igneous rocks related to intraplate extension triggered by subduction (Wu et al. 2011; Yang et al. 2012; Yu et al. 2012) and some Palaeozoic igneous rocks (Meng et al. 2011; Wang et al. 2012a, b). The age distribution map (Fig. 9) shows that approximately 210-170 Ma magmatism is not present in the Jiamusi Block, and is mainly distributed in the LXR and ZR (to the west of the Mudanjiang Fault) on the eastern margin of the Songliao Block.

Hence, the Hegang Basin had two main provenances: the LXR and the Jiamusi Block. At about $122 \mathrm{Ma}$, the Hegang Basin received sediments from both of these sources; however, at around $103 \mathrm{Ma}$, when the Houshigou Formation was deposited, the LXR source was no longer available. Considering the seismic structure of the Hegang Basin and the fact that the Chengzihe, Muling and Dongshan formations thicken eastwards with westwards onlap on to the basement, whereas the Houshigou Formation has no change in thickness, we propose that the Hegang Basin was separated from the Songliao Basin by the LXR when the Chengzihe, Muling and Dongshan formations were deposited but was connected to the Songliao Basin across the LXR when the Houshigou Formation was deposited at some time between 122 and $103 \mathrm{Ma}$.

\section{Connection to the Songliao Basin}

If the Hegang Basin was eventually connected with the Songliao Basin in Aptian-Albian time, the latter 
M. SUN ET AL.

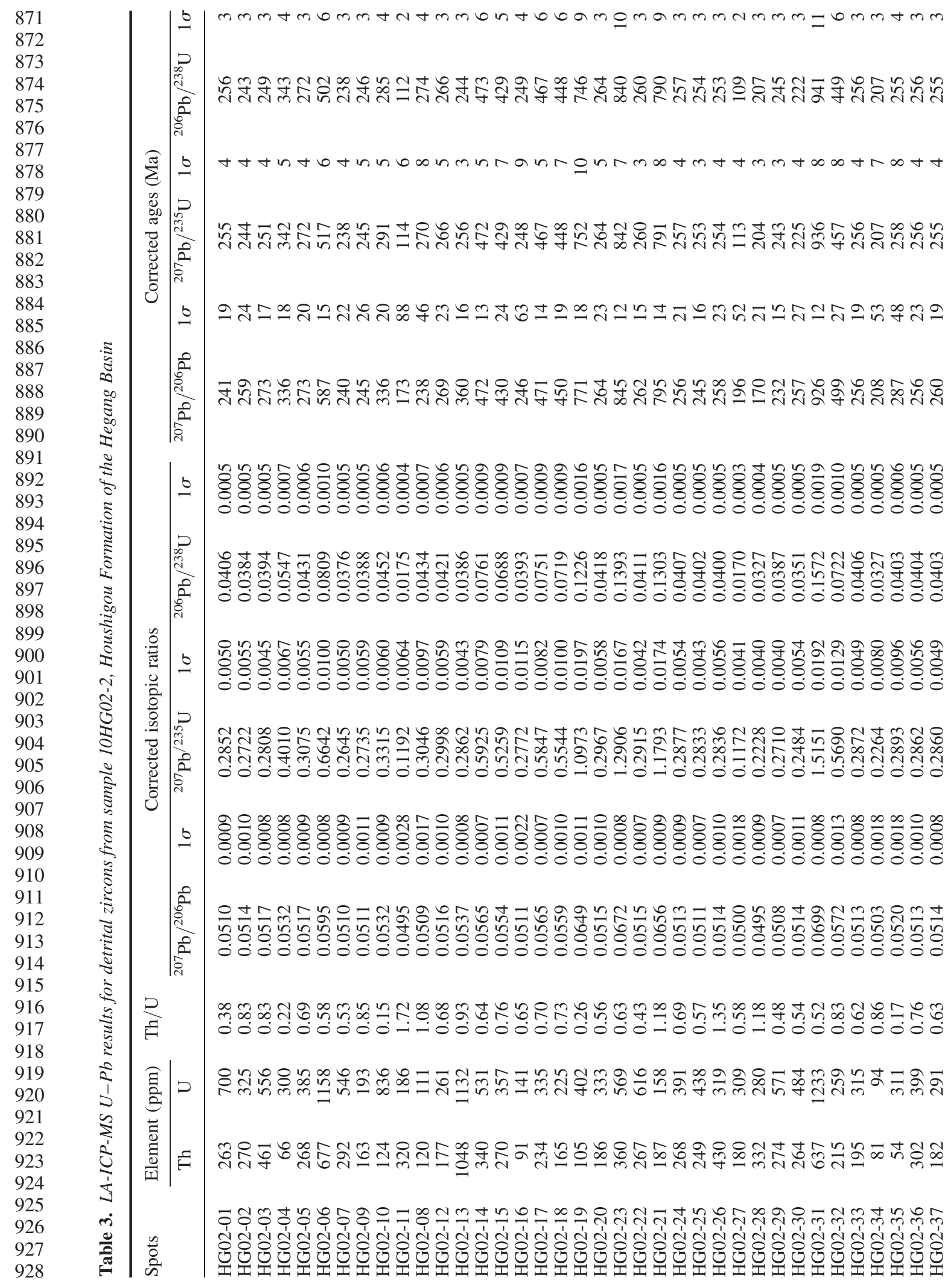


EVOLUTION OF CRETACEOUS BASINS, NE CHINA

ONmmmmmm n

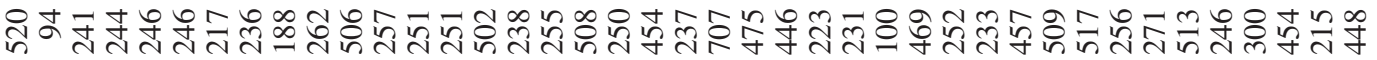
ம

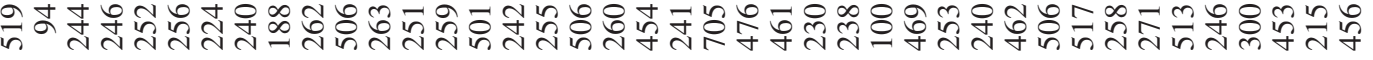

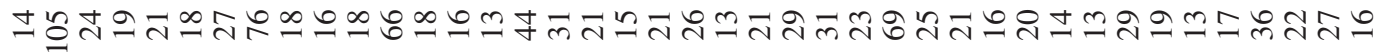

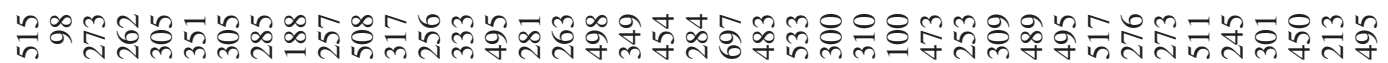

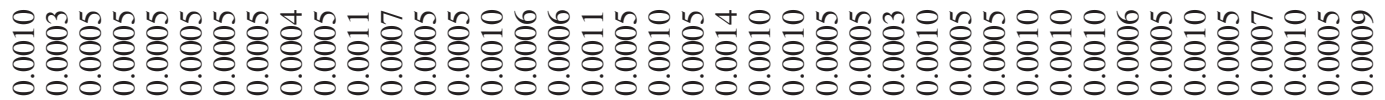

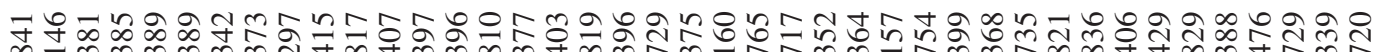

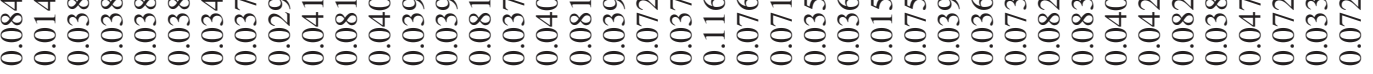

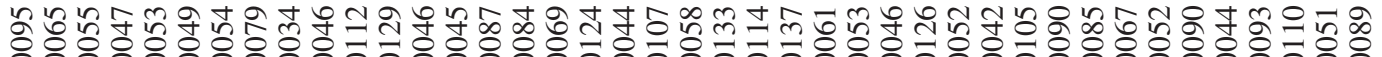

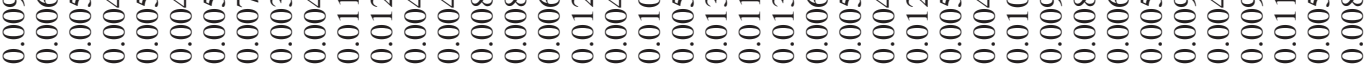

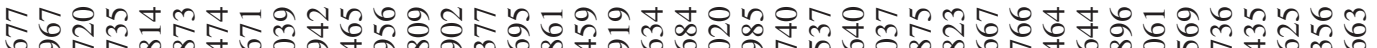

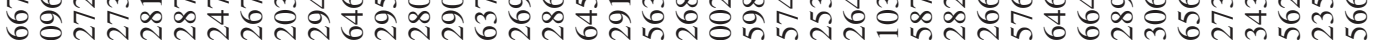
○’

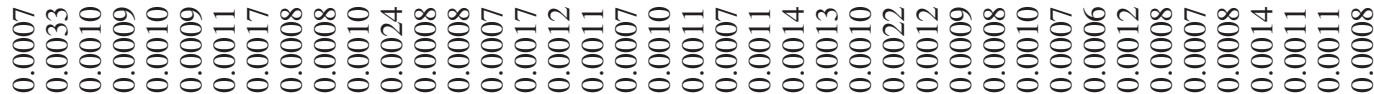

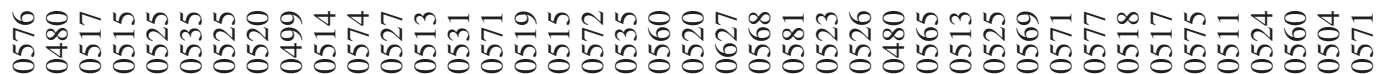

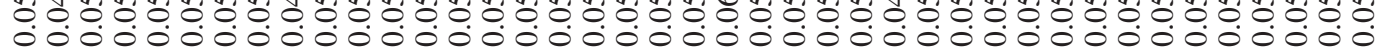

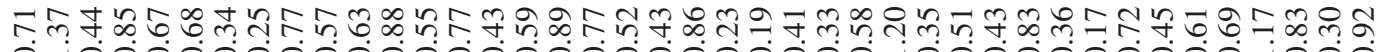
o. б্ল

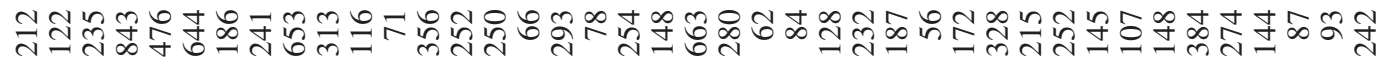

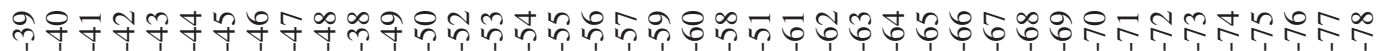
ฮิ่

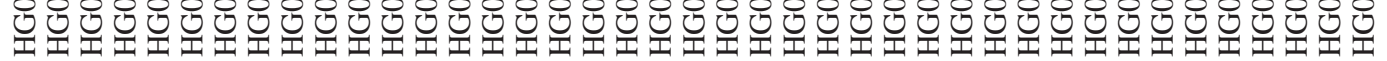


M. SUN $E T A L$.

\begin{tabular}{|c|c|c|c|c|}
\hline \multicolumn{5}{|r|}{$m m m m n t m+n \sigma+m m b m+m m$} \\
\hline 988 & & & & \\
\hline 989 & & & $\triangleright$ & \\
\hline 990 & & & 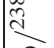 & 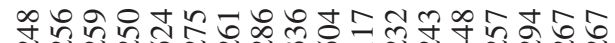 \\
\hline 991 & & & $\hat{\imath}$ & \\
\hline 992 & & & $\overbrace{\substack{1\\
}}^{1}$ & \\
\hline 993 & & & & \\
\hline 994 & & $\sum^{\pi}$ & $\stackrel{b}{=}$ & $\forall \forall n+a n m r O b \cong \forall+\sigma \forall r+\forall$ \\
\hline 995 & & s & D & \\
\hline 996 & & $\underset{\infty}{\infty}$ & $\infty_{\infty}^{2}$ & \\
\hline 997 & & 总 & $\int^{9}$ & ปั่ \\
\hline 998 & & 巳ँ & $\underline{2}$ & \\
\hline 999 & & Е & I) & \\
\hline 1000 & & & 6 & 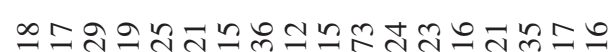 \\
\hline 1001 & & & - & 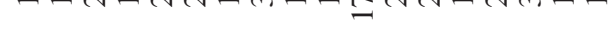 \\
\hline 1002 & & & & \\
\hline 1003 & & & $\overline{\underline{a}}$ & \\
\hline 1004 & & & $\overbrace{}^{\frac{1}{2}}$ & 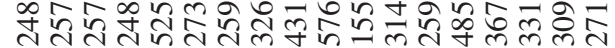 \\
\hline 1005 & & & $\hat{2}$ & \\
\hline 1006 & & & 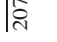 & \\
\hline 1007 & & & & \\
\hline 1008 & & & $b$ & 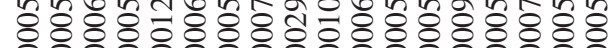 \\
\hline 1009 & & & & 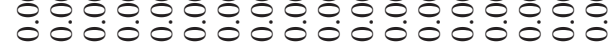 \\
\hline 1010 & & & & \\
\hline 1011 & & & 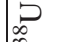 & \\
\hline 1012 & & & $\overbrace{}^{\tilde{n}}$ & 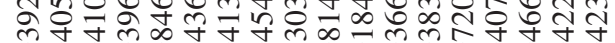 \\
\hline 1013 & & & $\hat{\imath}$ & 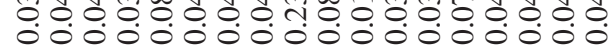 \\
\hline 1014 & & & (ְ) & \\
\hline 1015 & & \& & & \\
\hline 1016 & & 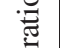 & 6 & 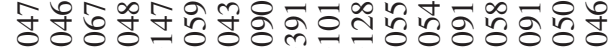 \\
\hline 1017 & & .0 & & 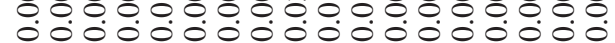 \\
\hline 1018 & & 官 & & \\
\hline 1019 & & .0 & $\infty$ & \\
\hline 1020 & & "ृ. & 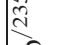 & 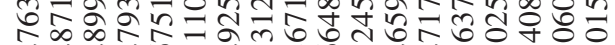 \\
\hline 1021 & & 气 & $\hat{2}$ & 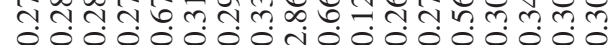 \\
\hline 1022 & & ڤ్ & ì & \\
\hline 1023 & & U & & $\infty \infty a \infty m a n-\infty a-000+\infty r$ \\
\hline 1024 & & & $b$ & ᄋᄋ- \\
\hline 1025 & & & & 0 \\
\hline 1026 & & & & \\
\hline 1027 & & & $\hat{\imath}$ & \\
\hline 1028 & & & 芒 & 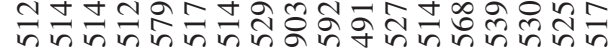 \\
\hline 1029 & & & $\frac{0}{2}$ & 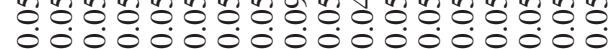 \\
\hline 1030 & & & 究 & \\
\hline 1031 & & & & \\
\hline 1032 & & 2 & & 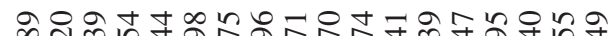 \\
\hline 1033 & & E & & $0000000000000000-0$ \\
\hline 1034 & & & & \\
\hline 1035 & & $\widehat{\Xi}$ & & 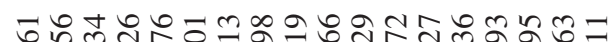 \\
\hline 1036 & & 范 & 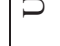 & 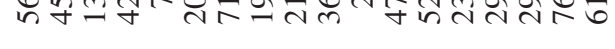 \\
\hline 1037 & & $=$ & & \\
\hline 1038 & $\Xi$ & $\stackrel{\bar{\Xi}}{\Xi}$ & & 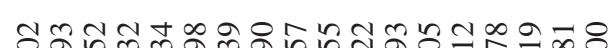 \\
\hline 1039 & $\cdot \tilde{\Xi}$ & $\frac{\bar{\Delta}}{\bar{I}}$ & E & 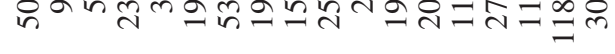 \\
\hline $\begin{array}{l}1040 \\
1041\end{array}$ & ن & & & 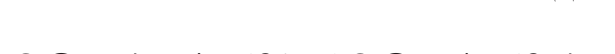 \\
\hline $\begin{array}{l}1041 \\
1042\end{array}$ & $\dot{r}$ & & & श्र \\
\hline 1043 & $\frac{0}{2}$ & $\tilde{0}$ & & 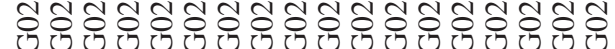 \\
\hline 1044 & $\tilde{\sigma}$ & के & & 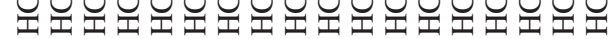 \\
\hline
\end{tabular}


EVOLUTION OF CRETACEOUS BASINS, NE CHINA

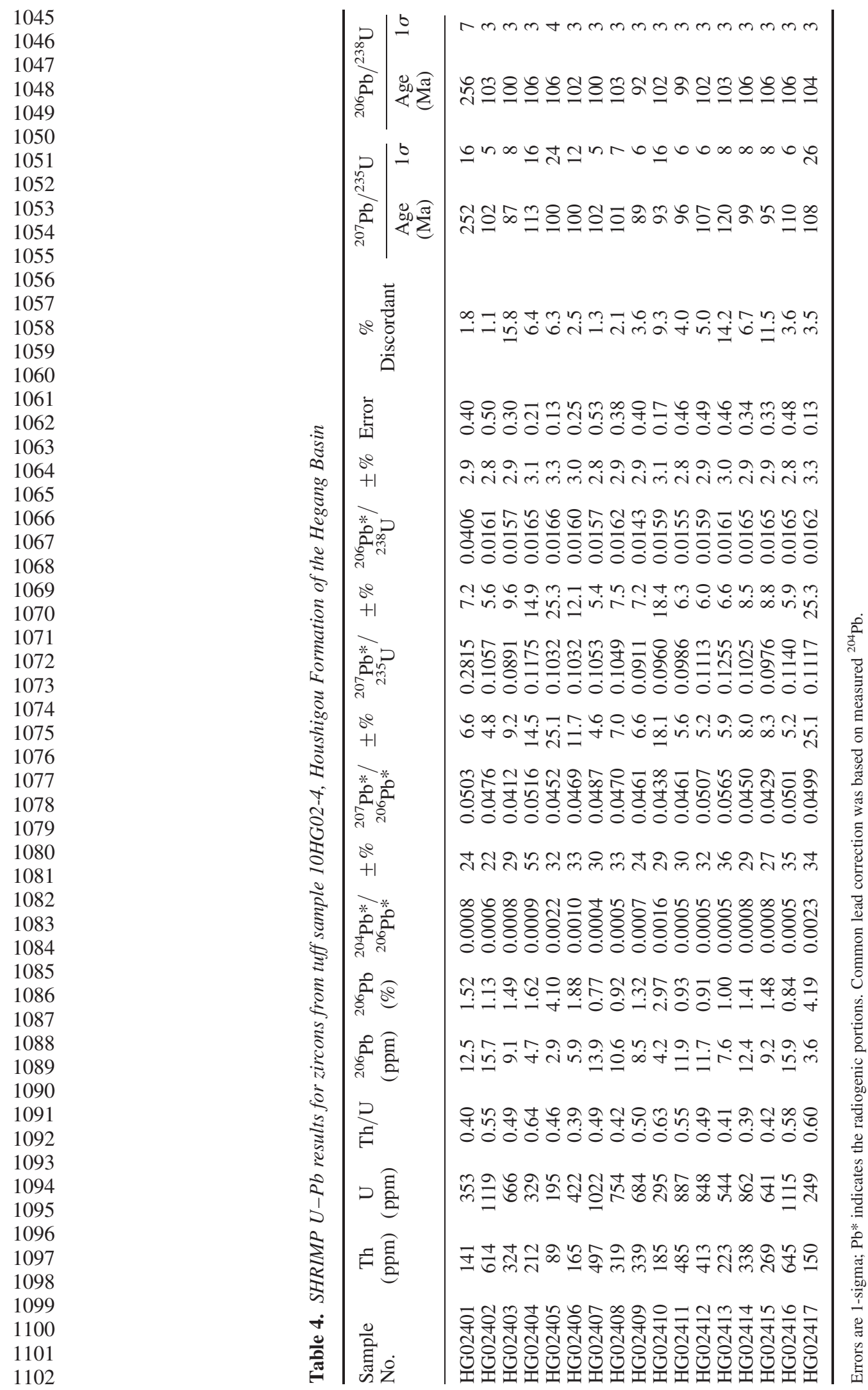




\section{SUN ET AL.}

\begin{tabular}{|c|c|c|c|c|}
\hline $\begin{array}{l}1103 \\
1104\end{array}$ & & & 10 & 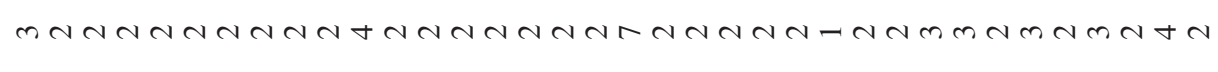 \\
\hline 1105 & & & $\infty$ & \\
\hline 1106 & & & 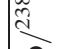 & 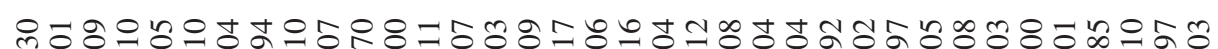 \\
\hline 1107 & & & $\hat{\imath}$ & 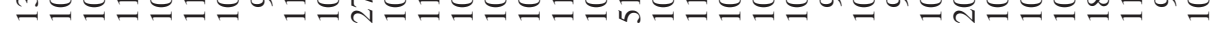 \\
\hline 1108 & & & & \\
\hline 1109 & & త్ & $b$ & OmmmaNNmRmbmmNNm+mnm+mmtmntanmNNnn=n \\
\hline 1110 & & $\sum$ & - & द \\
\hline 1111 & & $\underbrace{\infty}_{0}$ & מי & \\
\hline 1112 & & త్ & 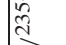 & 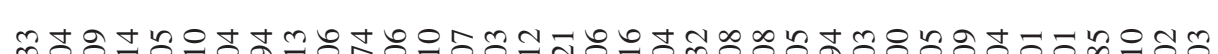 \\
\hline $\begin{array}{l}1113 \\
1114\end{array}$ & & $\frac{\pi}{0}$ & $\frac{\hat{2}}{2}$ & 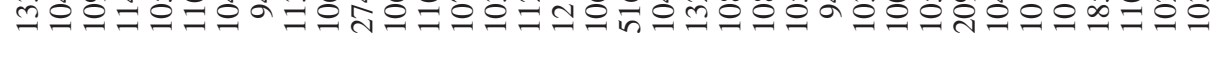 \\
\hline $\begin{array}{l}1114 \\
1115\end{array}$ & & 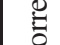 & & \\
\hline 1116 & & U & 6 & 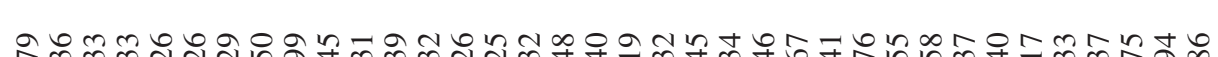 \\
\hline 1117 & & & & 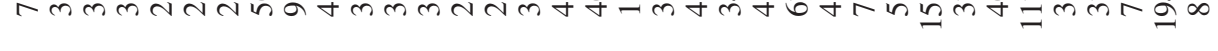 \\
\hline 1118 & $\cdot \tilde{3}$ & & 2 & \\
\hline 1119 & 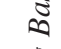 & & 苗 & \\
\hline $\begin{array}{l}1120 \\
1121\end{array}$ & $\stackrel{\infty}{\tilde{E}}$ & & $\frac{1}{2}$ & $\infty$ 거응ㅇㅇ읭ㅇㄱ \\
\hline 1122 & $\stackrel{\infty}{x}$ & & |î̀ & \\
\hline 1123 & $\approx$ & & & \\
\hline 1124 & $\frac{\pi}{2}$ & & $\underline{b}$ & 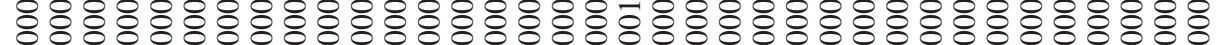 \\
\hline 1125 & $\Xi$ & & & 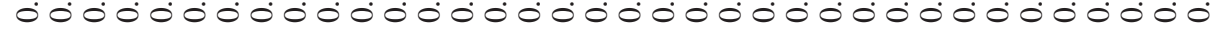 \\
\hline 1126 & 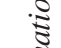 & & & \\
\hline 1127 & ह & & तֶर & 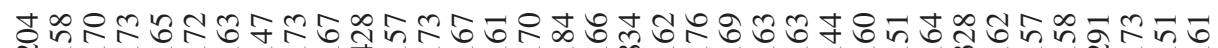 \\
\hline 1128 & 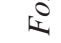 & & 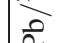 & 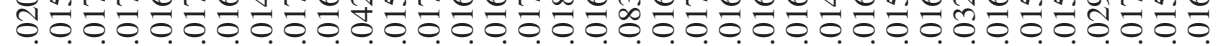 \\
\hline 1129 & $\Xi$ & & (ب) & 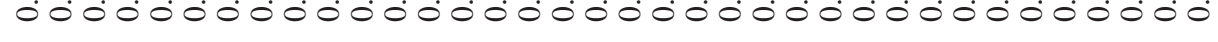 \\
\hline 1130 & $\stackrel{\infty}{\approx}$ & & & \\
\hline 1131 & $\bar{\Xi}$ & $\stackrel{0}{\stackrel{\Xi}{\Xi}}$ & & 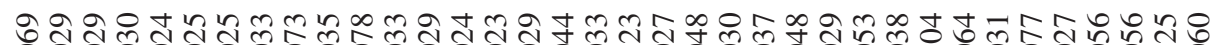 \\
\hline 1132 & 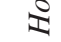 & $\underset{0}{0}$ & $\underline{6}$ & 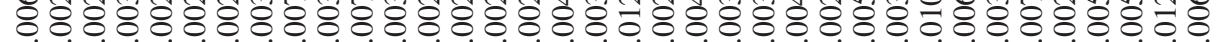 \\
\hline 1133 & $\varphi^{0}$ & ㄴ. & & 000000000000000000000000000000000000 \\
\hline 1134 & $\stackrel{1}{\check{1}}$ & $\frac{0}{0}$ & D & \\
\hline 1135 & 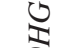 & $\stackrel{20}{2}$ & 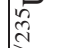 & 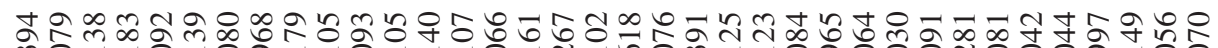 \\
\hline 1136 & $\sqrt{2}$ & $\stackrel{\Perp}{0}$ & $\frac{0}{2}$ & 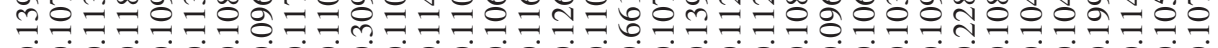 \\
\hline 1137 & 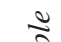 & $\mathscr{\mathscr { V }}$ & 宽 & 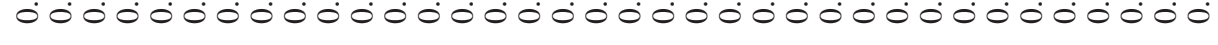 \\
\hline 1138 & ह્ફ & తి & & \\
\hline 1139 & $\begin{array}{c}5 \\
5 \\
5\end{array}$ & & & 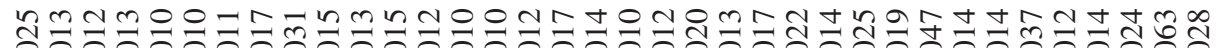 \\
\hline 1140 & క & & $\underline{\theta}$ & \& \& \& \& \& \& \& \& \& \& \& \& \& \& \& \& \& \& \& \& \& \& \& \& \& \& \& \& \& \& \& \& \& \& \& \& \\
\hline 1141 & 5 & & & 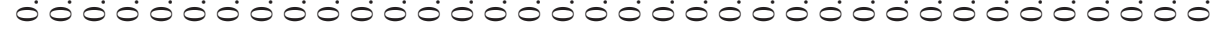 \\
\hline 1142 & $\stackrel{8}{2}$ & & 2 & \\
\hline 1143 & $\cdot \stackrel{\vec{N}}{2}$ & & 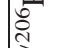 & ลேڤ \\
\hline 1144 & $\widetilde{z}$ & & 2 & 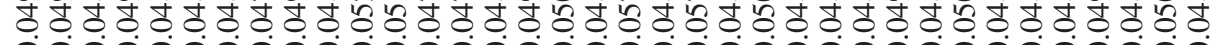 \\
\hline 1145 & $\stackrel{\Sigma}{5}$ & & 告 & 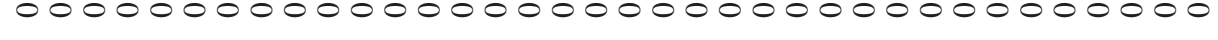 \\
\hline 1146 & $\approx$ & & & \\
\hline 1147 & $\dot{s}$ & 2 & & 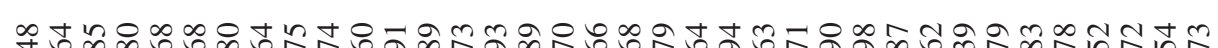 \\
\hline $\begin{array}{l}1148 \\
1149\end{array}$ & $\stackrel{\Xi}{\Xi}$ & 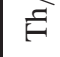 & & 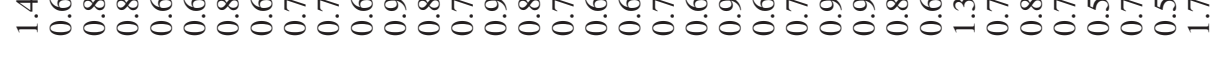 \\
\hline 1150 & $\stackrel{2}{2}$ & $\approx$ & & \\
\hline 1151 & $\overrightarrow{2}$ & 言 & $\triangleright$ & 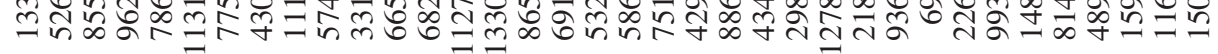 \\
\hline 1152 & 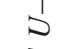 & $=$ & & \\
\hline 1153 & $\Sigma$ & 巳ँ & & \\
\hline $\begin{array}{l}1154 \\
1155\end{array}$ & $\hat{U}^{\prime}$ & $\frac{\bar{Q}}{\frac{\vec{\nu}}{I I}}$ & E & 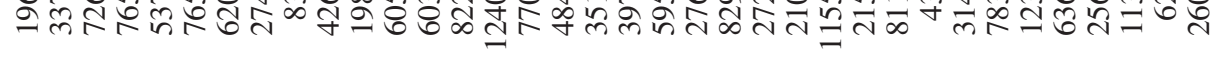 \\
\hline 1156 & I & & & \\
\hline 1157 & & & & 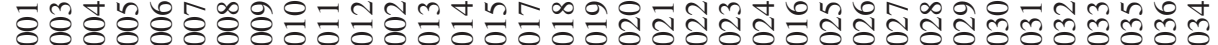 \\
\hline 1158 & $\stackrel{0}{0}$ & & & مَإ 100 \\
\hline 1159 & न & ¿ & & 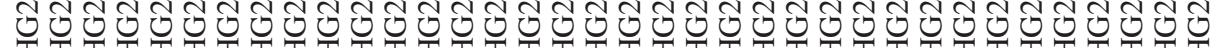 \\
\hline 1160 & & $\omega$ & & 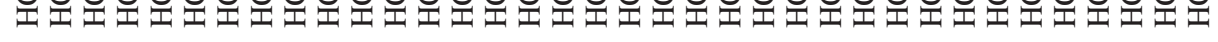 \\
\hline
\end{tabular}




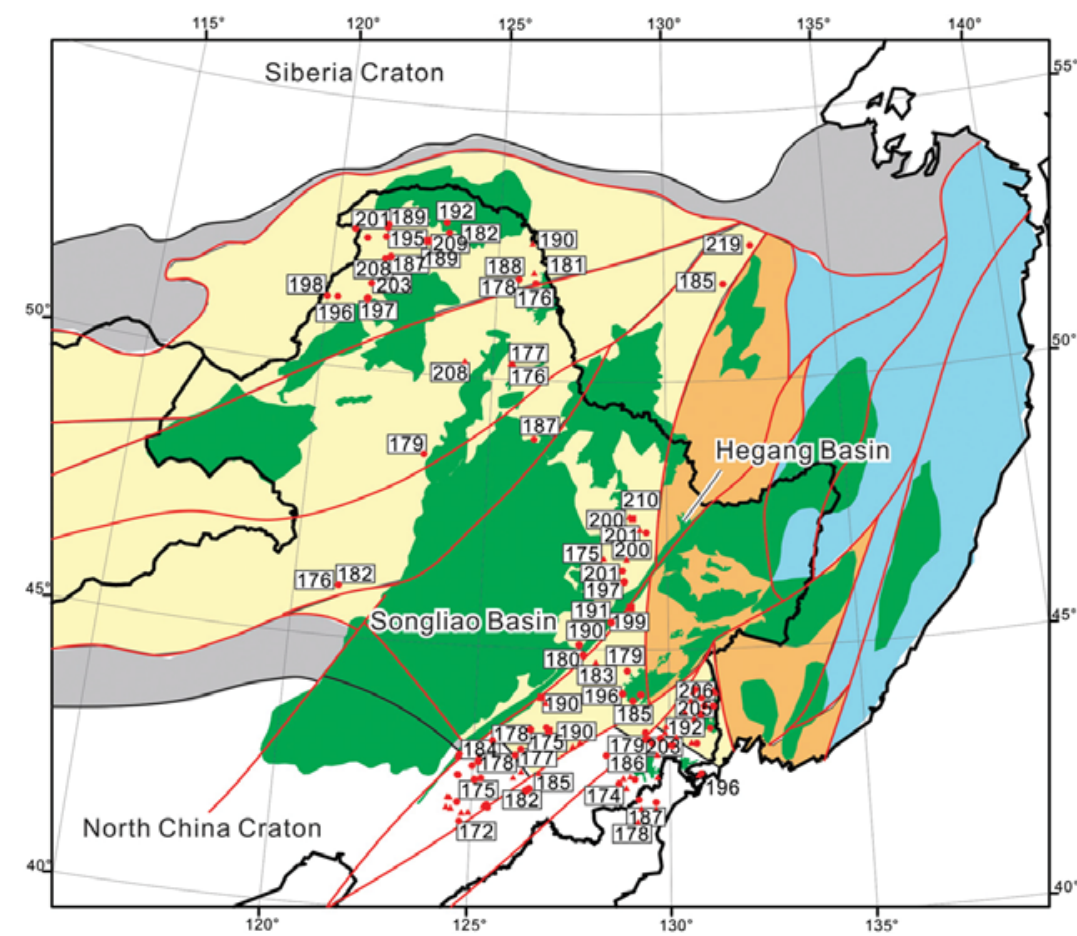

Fig. 9. Map of NE China and adjacent areas showing the igneous rock distribution (c. 210-170 Ma) and highlighting that the Jiamusi Block has no Late Triassic-Early Jurassic magmatism. Data are from Wu et al. (2011), Yang et al. (2012) and Yu et al. (2012).

should also record the same change in provenance in the late Early Cretaceous.

The tuff at the top of the Houshigou Formation has an age of $103 \pm 2 \mathrm{Ma}$, whereas the youngest age group from the Chengzihe Formation has a peak age of $122 \pm 2 \mathrm{Ma}$. It appears likely that the Chengzihe, Muling and Dongshan formations in the Hegang Basin correspond to the Shahezi, Yingcheng and Denglouku formations, respectively, in the Songliao Basin (Feng et al. 2010a, b; Li et al. 2012). Also, the Houshigou Formation in the Hegang Basin corresponds to the Quantou Formation of the Songliao basin (Zhao et al. 2013) (Fig. 10).

The Denglouku Formation in the Songliao Basin contains approximately $180 \mathrm{Ma}$ detrital zircons that were most probably also derived from the LXR, further suggesting that the LXR was a highland and the two basins were not connected at this time. However, there is no evidence of such an Early Jurassic provenance in the Quantou Formation in the Songliao Basin (Fig. 11), indicating that the LXR was not an existing barrier at this time, and that the Songliao Basin was connected to the Hegang Basin across the LXR when the Yaojia Formation in the Songliao Basin and Houshigou Formation in the Hegang Basin were deposited. It is important to note that the Quantou Formation in the Songliao Basin has 1.8 Ga provenance zircons (most probably derived from the North China Craton), whereas the Houshigou Formation in the Hegang Basin does not contain these. This is possibly because the connection between the Hegang and Songliao basins was restricted. The Lesser Xing'an Range was probably still an uplift area beneath the water and this blocked detritus from the North China Craton into the Hegang Basin. This could explain why only the Songliao Basin contains $1.8 \mathrm{Ga}$ zircons of North China Craton provenance.

The early Late Cretaceous Yaojia Formation in the Songliao Basin also contains no Early Jurassic zircons (Fig. 11), suggesting that the Songliao Basin possibly flooded over the LXR during the whole of its post-rift stage from the Quantou Formation to the Yaojia Formation, as per the subdivision suggested by Feng et al. (2010a). This leaves the question of when were the Songliao and Hegang basins again separated by the LXR as occurs at the present time? Li et al. (2012) indicated that the fourth member (as shown in Fig. 10) of the Nenjiang Formation in the Songliao Basin does contain an early Jurassic provenance (Fig. 11), so the second separation of the Hegang and Songliao basins must have occurred at the time when the fourth member of the Nenjiang formation was deposited. Importantly, this also marks the beginning of the structural inversion of the Songliao Basin (Feng et al. 2010a, b). 


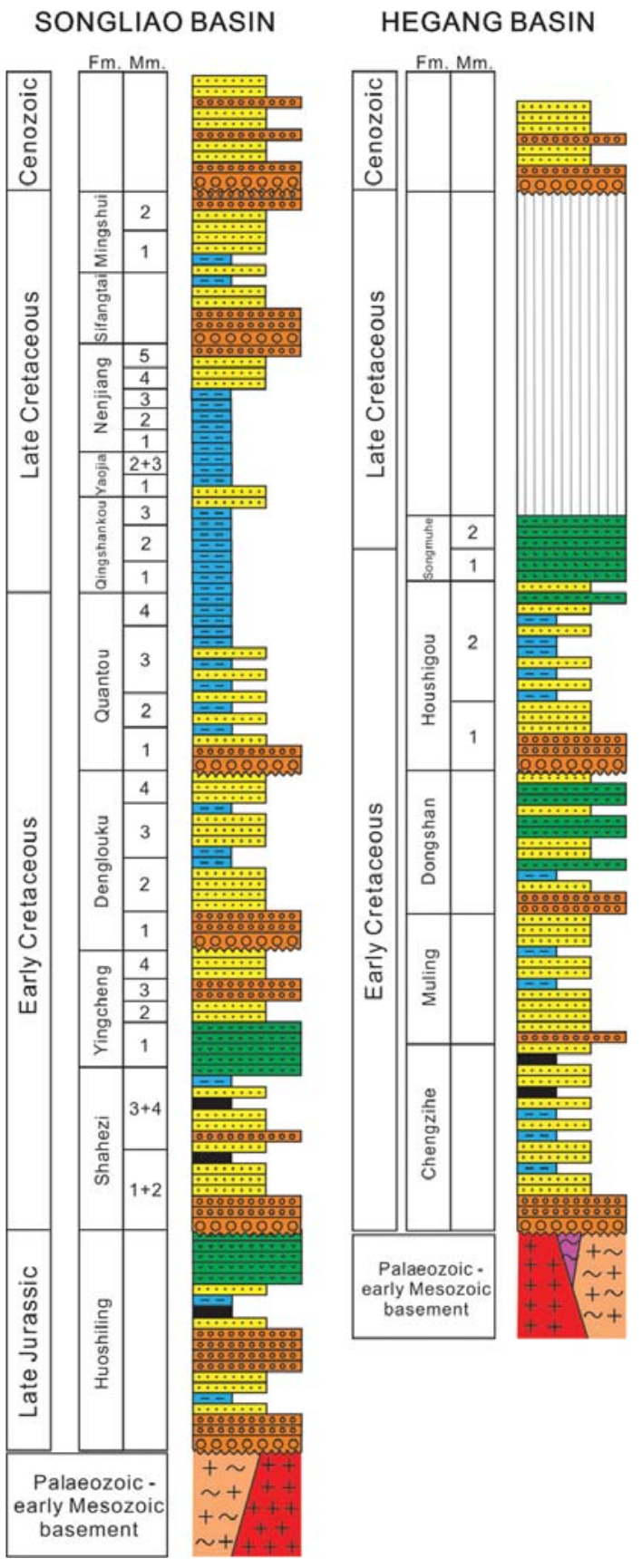

Fig. 10. Stratigraphy of the Songliao and Hegang basins. The column for the Songliao Basin follows Feng et al. (2010a); the column for the Hegang Basin is based on the Hegang and Jiamusi 1:200 000 geological maps.

\section{Depositional model and tectonic implications}

In summary, the Songliao and Hegang basins formed a unified system in the Cretaceous. We identify four stages that illustrate the evolution of

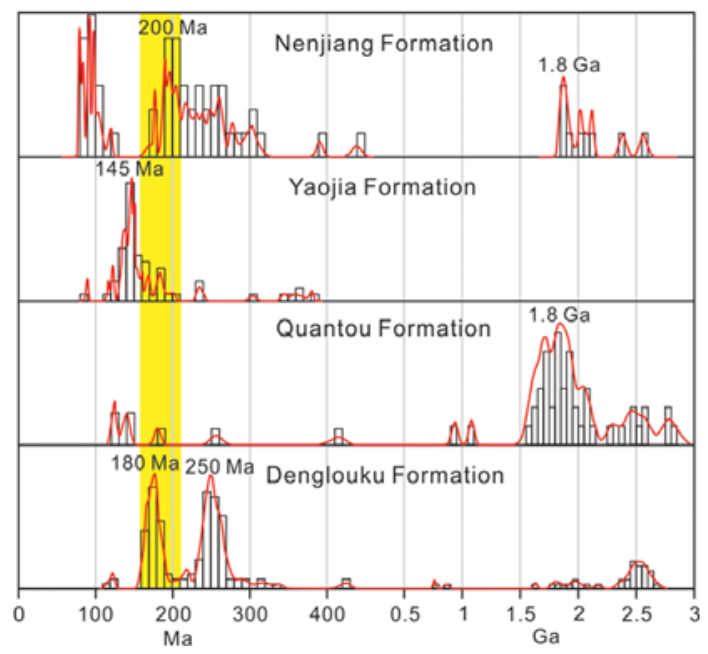

Fig. 11. Detrital zircon data for the Denglouku, Quantou, Yaojia and Nenjiang formations of the Songliao Basin. Data are from Li et al. (2012) and Zhao et al. (2013).

the Songliao and Hegang basin system (see Fig. 12a): synrift, post-rift, inversion and present day, following the model developed for the Songliao Basin (Feng et al. 2010a). In the synrift stage, the LXR was a highland. The Songliao and Hegang basins received sediments from the LXR during the Barremian-Early Albian, resulting in deposition of the Denglouku Formation in the Songliao Basin, and the Chengzihe, Muling and Dongshan formations in the Hegang Basin. In the post-rift stage, the LXR was under water and unable to provide detritus to the evolving basins. The Songliao and Hegang basins were then connected, and this led to the deposition of the Quantou, Qingshankou, Yaojia and Nenjiang formations in the Songliao Basin, and the Houshigou Formation in the Hegang Basin. In the inversion stage, the eastern part of the Songliao Block and the Jiamusi Block were uplifted, and the LXR, again, provided detritus to the Songliao Basin, while there was no deposition in the Hegang Basin. At the present time, the LXR is being eroded and separates the Songliao Basin from the Hegang Basin.

The schematic depositional model (Fig. 12a) best explains the provenance change and indicates a process of eastwards migration of the depositional centre of the Songliao and Hegang basin system, and also a lateral reverse event after the extension. However, greater consideration of the tectonic implications is needed.

Considering the direction of the migration and regional tectonic background, this process was most possibly triggered by the palaeo-Pacific Ocean to the east rather than subduction of the 


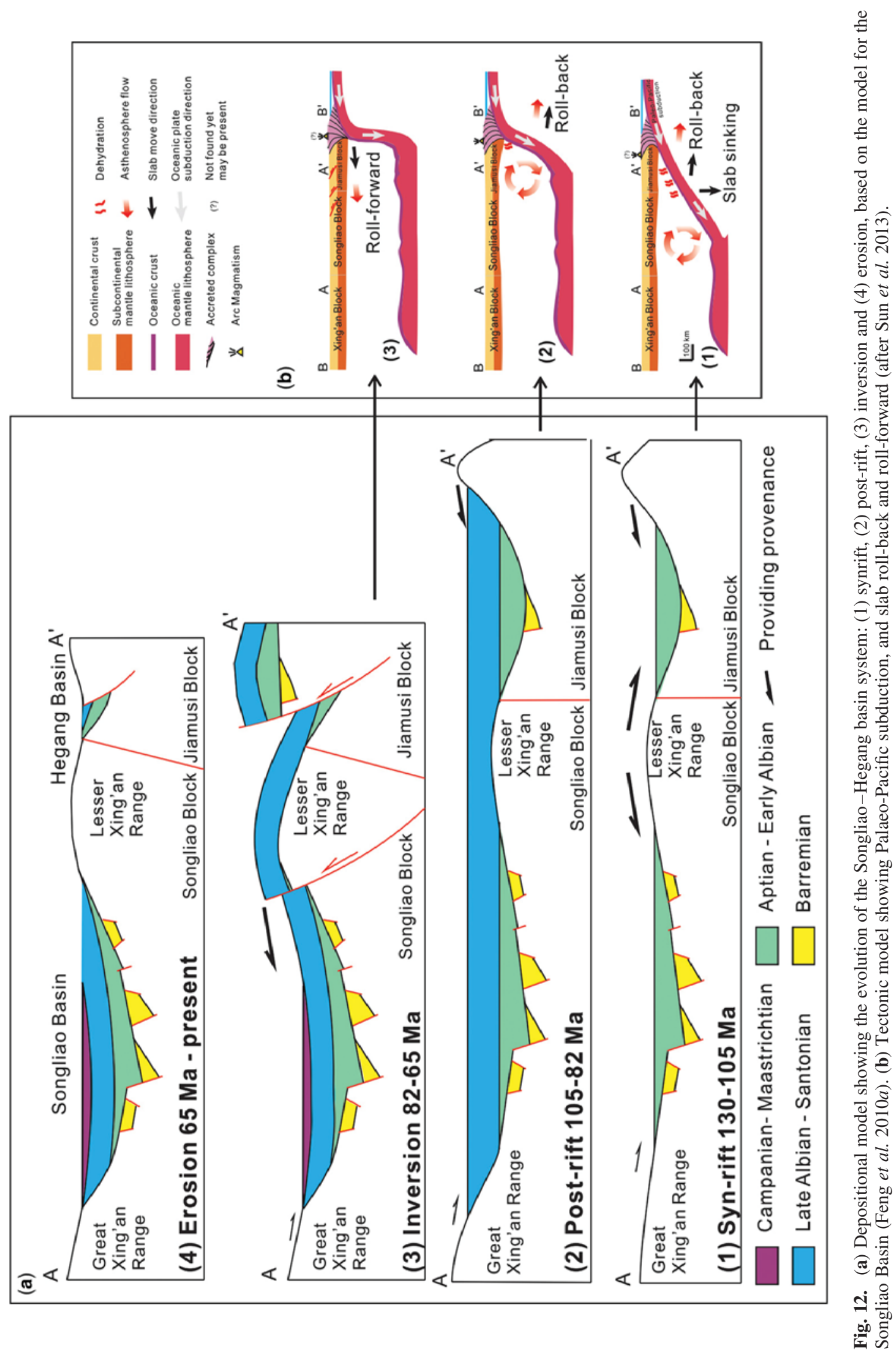


Mongol-Okhotsk Ocean to the north, as the Mongol-Okhotsk Ocean was closed in the Early Cretaceous (Cogne et al. 2005), whereas the events recorded in this study mainly occurred in the midCretaceous. Slab roll-back and roll-forward are two major models controlling the geological evolution of continental margins affected by oceanic subduction (Schellart et al. 2008). Thus, a tectonic model with a sequence of slab roll-back and rollforward for the palaeo-Pacific subduction is built as shown in Figure 12b to interpret the evolution of the Hegang and Songliao basins.

The evolution of the subduction model is divided into three stages as shown in Figure 12b (1) In the first stage, the slab subducted to the mantle beneath the Songliao Basin. The mantle convection area and the extensional centre were also beneath/at the Songliao Basin. (2) In the second stage, the slab rolled back and the subducting slab angle increased, triggered by slab sinking. The mantle convection area and the extensional centre migrated eastwards beneath the Hegang Basin, causing the eastwards migration of the depositional centre and the connection between the Hegang and Songliao basins. (3) In the third stage, the slab subducting angle increased to nearly vertical, and the slab sinking could no longer trigger slab roll-back or an increase in the slab angle, so extension stopped instead of resulting in a regional uplift and thrust event.

The above tectonic model not only satisfies the sedimentary evolution of the Hegang and Songliao basins but is also consistent with a previous model postulated according to the magmatic evolution of NE China at this time (Sun et al. 2013).

\section{Conclusions}

Our new detrital zircon data from the Chengzihe and Houshigou formations in the Hegang Basin, combined with our SHRIMP data from a tuff at the top of the Houshigou Formation, allow us to evaluate the provenance of detritus entering the Hegang Basin and to also place a precise timeline on the age of the Houshigou Formation. When these data are combined with the seismic structure of the Hegang Basin, an evaluation of the stratigraphy in both the Hegang and Songliao basins, an evaluation of previously published detrital zircon data for the Songliao Basin and an overview of the regional tectonic setting, we are able to make the following conclusions:

- The Hegang Basin is a Cretaceous coal-bearing clastic sedimentary basin in which the Chengzihe, Muling and Dongshan formations thicken eastwards with westwards onlap on to the LXR, whereas the Houshigou Formation shows no change in thickness.
- The SHRIMP zircon age of a tuff from the upper part of the Houshigou Formation in the Hegang Basin is $103 \pm 2 \mathrm{Ma}$, implying that the Houshigou Formation is equivalent to the Quantou Formation in the Songliao Basin.

- The Chengzihe Formation of the Hegang Basin and the Denglouku Formation of the Songliao Basin show striking similarities in their detrital zircon provenance, with approximately $180 \mathrm{Ma}$ zircons indicating that the Lesser Xing' an Range was possibly a highland at this time and able to provide detritus to the evolving basins.

- The Houshigou Formation of the Hegang Basin and the Quantou Formation of the Songliao Basin both lack zircons with ages of around $180 \mathrm{Ma}$, which suggests that the Lesser Xing'an Range was possibly under water and unable to provide detritus during the post-rift stage.

- The Songliao and Hegang basins show an eastwards migration of the deposition centre of the Cretaceous basin system in NE China. This implies lithospheric extension and, when taken in a regional context, this was most probably driven by palaeo-Pacific roll-back.

We appreciate the assistance of B. Wu and D.-X. Chen during LA-ICP-MS analysis. H.-Q. Xie and G.-H. Gong helped with the SHRIMP analysis. We also thank C.-W. Dong, X.-Q. Zhao, Y. Xu, J. Xiao, L.-M. Tang and $\mathrm{X}$. Yu for help in the field and with sample pretreatment. Thanks to G. Gibson, W. Xiao and an anonymous reviewer for their significant contribution to the final quality of the manuscript. This work was supported by the National Science and Technology Major Project (grant No. 2011ZX05009-001), the National Natural Science Foundation of China (grant No. 41272231, 41330207) and the Zhejiang Provincial Natural Science Foundation of China (grant No. Y5100131). It is TIGeR (The Institute for Geoscience Research) paper No. 483.

\section{References}

ANDERSEN, T. 2002. Correction of common lead in $\mathrm{U}-\mathrm{Pb}$ analyses that do not report Pb-204. Chemical Geology, 192, 59-79.

Black, L. P. \& Gulson, B. L. 1978. The age of the Mud Tank carbonatite, Strangways Range, Northern Territory. BMR Journal of Australian Geology and Geophysics, 3, 227-232.

Black, L. P., Kamo, S. L., Allen, C. M., Aleinikoff, J. N., Davis, D. W., Korsch, R. J. \& Foudoulis, C. 2003. TEMORA 1: a new zircon standard for Phanerozoic U-Pb geochronology. Chemical Geology, 200, $155-170$.

Cawood, P. A., Nemchin, A. A., Freeman, M. \& SirCOMBE, K. 2003. Linking source and sedimentary basin: detrital zircon record of sediment flux along a modern river system and implications for provenance studies. Earth and Planetary Science Letters, 210. 259-268. 


\section{EVOLUTION OF CRETACEOUS BASINS, NE CHINA}

Cawood, P. A., Hawkesworth, C. J. \& Dhuime, B. 2012 Detrital zircon record and tectonic setting. Geology, 40, 875-878.

Cogne, J. P., Kravchinsky, V. A., Halim, N. \& HANKARD, F. 2005. Late Jurassic-Early Cretaceous closure of the Mongol-Okhotsk Ocean demonstrated by new Mesozoic palaeomagnetic results from the Trans-Baikal area (SE Siberia). Geophysical Journal International, 163, 813-832.

Dickinson, W. R. \& Gehrels, G. E. 2009. Use of U-Pb ages of detrital zircons to infer maximum depositional ages of strata: a test against a Colorado Plateau Mesozoic database. Earth and Planetary Science Letters, 288, $115-125$.

Drewery, S., Cliff, R. A. \& Leeder, M. R. 1987. Provenance of carboniferous sandstones from $\mathrm{U}-\mathrm{Pb}$ dating of detrital zircons. Nature, 325, 50-53.

Feng, Z. Q., Jia, C. Z., XIE, X. N., Zhang, S., Feng, Z. H. \& Cross, T. A. 2010a. Tectonostratigraphic units and stratigraphic sequences of the nonmarine Songliao basin, northeast China. Basin Research, 22, 79-95.

FenG, Z. Q., Zhang, S. ET AL. 2010b. Lacustrine turbidite channels and fans in the Mesozoic Songliao Basin, China. Basin Research, 22, 96-107.

FenG, Z. H., FANG, W. ET AL. 2011. Depositional environment of terrestrial petroleum source rocks and geochemical indicators in the Songliao Basin. Science China Earth Sciences, 54, 1304-1317.

Feng, Z., Wang, C., Graham, S., Koeberl, C., Dong, H., HuANG, Y. \& GAO, Y. 2013. Continental scientific drilling project of cretaceous Songliao basin: scientific objectives and drilling technology. In: WANG, C. Graham, S. A., Parrish, J. T. \& Wan, X. (eds) Environmental/Climate Change in the Cretaceous Greenhouse World: Records from Terrestrial Scientific Drilling of Songliao Basin and Adjacent Area of China. Palaeogeography, Palaeoclimatology, Palaeoecology, 385, 6-16.

GaO, F. H., Xu, W. L., Yang, D. B., Pei, F. P., Liu, X. M \& Hu, Z. C. 2007. LA-ICP-MS zircon U-Pb dating from granitoids in southern basement of Songliao basin: constraints on ages of the basin basement. Science in China Series D, 50, 995-1004.

GAO, Y. F., WANG, P. J., QU, X. J. \& WANG, G. D. 2010. Sedimentary facies and cyclostratigraphy of the Cretaceous first member of Nenjiang Formation in the Southeast uplift zone, Songliao Basin and its correlation with the CCSD-SK-I. Acta Petrologica Sinica, 26, 99-108.

Gu, Z. W., LI, Z. S. \& Yu, X. H. 1997. Lower Cretaceous Bivalves from the Eastern Heilongjiang Province of China. Science Press, Beijing.

Huang, Q. H., Yang, J. G. \& Kong, H. 2003. The Fangzheng Formation of the Fangzheng Rift in the Northeast of the Yilan-Yitong Rift Valley and its significance. Journal of Stratigraphy, 27, 138-145. [in Chinese with English abstract].

JACKSON, M. \& Sherman, G. D. 1953. Chemical weathering of minerals in soils. Advances in Agronomy, 5, 317.

Jackson, S. E., Pearson, N. J., Griffin, W. L. \& Belousova, E. A. 2004. The application of laser ablationinductively coupled plasma-mass spectrometry to in situ $\mathrm{U}-\mathrm{Pb}$ zircon geochronology. Chemical Geology, 211, 47-69.
Kotov, A. B., Velikoslavinskit, S. D. et al. 2009. Age of the Amur Group of the Bureya-Jiamusi Superterrane in the Central Asian Fold Belt: Sm-Nd Isotope evidence. Doklady Earth Sciences, 429, 1245-1248.

Kravchinsky, V. A., Cogne, J. P., Harbert, W. P. \& Kuzmin, M. I. 2002. Evolution of the MongolOkhotsk Ocean as constrained by new palaeomagnetic data from the Mongol-Okhotsk suture zone, Siberia. Geophysical Journal International, 148, 34-57.

Li, S.-Q., Chen, F., Siebel, W., Wu, J.-D., Zhu, X.-Y., Shan, X.-L. \& Sun, X.-M. 2012. Late Mesozoic tectonic evolution of the Songliao basin, NE China: evidence from detrital zircon ages and $\mathrm{Sr}-\mathrm{Nd}$ isotopes. Gondwana Research, 22, 943-955.

Li, Y. C., YANG, X. P., Zhou, X. F. \& WANG, H. J. 2006. Integrated stratigraphic correlation of the Jixi Group and Longzhaogou Group in eastern Heilongjiang China. Geology in China, 33, 1312-1320. [in Chinese with English abstract].

Li, Z. X., Zhang, L. H. \& Powell, C. M. 1995. South China in Rodinia - part of the missing link between Australia East Antarctica and Laurentia. Geology, 23, 407-410.

LiU, F. X. 2006. Bennettitales from Lower Cretaceous Chengzihe Formation in the Jixi basin of Heilongjiang, China. PhD thesis, Jilin University, 6-8.

LudwIG, K. R. 2001. Squid 1.03: A User's Manual. Berkeley Geochronology Center, Special Publications, 2. Berkeley, CA.

LuDwIG, K. R. 2003. User's Manual for Isoplot 3.0. A Geochronological Toolkit for Microsoft Excel. Berkeley Geochronology Center, Special Publications, 4. Berkeley, CA.

Meng, E., Xu, W. L., Pei, F. P., Yang, D. B., Yu, Y. \& ZhanG, X. Z. 2010. Detrital-zircon geochronology of Late Paleozoic sedimentary rocks in eastern Heilongjiang Province, NE China: implications for the tectonic evolution of the eastern segment of the Central Asian Orogenic Belt. Tectonophysics, 485, $42-51$.

Meng, E., Xu, W. L., Pei, F. P., Yang, D. B., Wang, F. \& Zhang, X. Z. 2011. Permian bimodal volcanism in the Zhangguangcai Range of eastern Heilongjiang Province, NE China: zircon $\mathrm{U}-\mathrm{Pb}-\mathrm{Hf}$ isotopes and geochemical evidence. Journal of Asian Earth Sciences, 41, 119-132.

Pei, F. P., Xu, W. L., Yang, D. B., Zhao, Q. G., LiU, X. M. \& Hu, Z. C. 2007. Zircon U-Pb geochronology of basement metamorphic rocks in the Songliao Basin. Chinese Science Bulletin, 52, 942-948.

Ren, J. Y., TAMAKI, K., LI, S. T. \& JunXIA, Z. 2002. Late Mesozoic and Cenozoic rifting and its dynamic setting in Eastern China and adjacent areas. Tectonophysics, 344, 175-205.

Riggs, N. R., Lehman, T. M., Gehrels, G. E. \& Dickinson, W. R. 1996. Detrital zircon link between headwaters and terminus of the upper Triassic ChinleDockum paleoriver system. Science, 273, 97-100.

Schellart, W. P., Stegman, D. R. \& Freeman, J. 2008. Global trench migration velocities and slab migration induced upper mantle volume fluxes: constraints to find an Earth reference frame based on minimizing viscous dissipation. Earth-Science Reviews, 88, $118-144$. 


\section{SUN ET AL.}

SHA, J. G. 2007. Cretaceous stratigraphy of northeast China: non-marine and marine correlation. Cretaceous Research, 28, 146-170.

Sha, J. G., CAI, H. W. ET AL. 2002. Studies on the Early Cretaceous Longzhaogou and Jixi Groups of eastern Heilongjiang, northeast China, and their bearing on the age of supposedly Jurassic strata in eastern Asia. Journal of Asian Earth Sciences, 20, 141-150.

Sha, J. G., Matsukawa, M., Cai, H. W., Jiang, B. Y., Ito, M., HE, C. Q. \& Gu, Z. W. 2003. The upper JurassicLower Cretaceous of eastern Heilongjiang, Northeast China: stratigraphy and regional basin history. Cretaceous Research, 24, 715-728.

Sha, J. G., WANG, J. P. ET AL. 2009. Upper Jurassic and lower cretaceous of Sanjiang-Middle Amur basin: nonmarine and marine correlation. Science in China Series $D, \mathbf{5 2}, 1873-1889$.

Sorokin, A. A., Kotov, A. B., Sal'nikova, E. B., Kudryashov, N. M., Anisimova, I. V., Yakovleva, S. Z. \& Fedoseenko, A. M. 2010. Granitoids of the Tyrma-Bureya complex in the northern BureyaJiamusi superterrane of the Central Asian fold belt: age and geodynamic setting. Russian Geology and Geophysics, 51, 563-571.

Sun, G. \& Dilcher, D. L. 2002. Early angiosperms from the Lower Cretaceous of Jixi, eastern Heilongjiang, China. Review of Palaeobotany and Palynology, 121, 91-112.

Sun, M. D., Chen, H. L., Zhang, F. Q., Wilde, S. A., Dong, C. W. \& YAng, S. F. 2013. A 100 Ma bimodal composite dyke complex in the Jiamusi Block, NE China: an indication for lithospheric extension driven by Paleo-Pacific roll-back. Lithos, 162, 317-330.

Sun, X. M., Long, S. X., Zhang, M. S., LiU, X. Y. \& HaO, F. J. 2006. Discovery and timing of major thrustbelt in Jiamusi-Yitong fault zone. Oil and Gas Geology, 27, 637-643. [in Chinese with English abstract].

Thомаs, W. A. 2011. Detrital-zircon geochronology and sedimentary provenance. Lithosphere, 3, 304-308.

WAN, Y. S., LI, R. W. ET AL. 2005. UHP metamorphism and exhumation of the Dabie Orogen, China: evidence from SHRIMP dating of zircon and monazite from a UHP granitic gneiss cobble from the Hefei Basin. Geochimica et Cosmochimica Acta, 69, $4333-4348$.

Wang, C., Feng, Z., Zhang, L., Huang, Y., CaO, K., WANG, P. \& ZHaO, B. 2013. Cretaceous paleogeography and paleoclimate and the setting of SKI borehole sites in Songliao Basin, northeast China. In: WANG, C., Graham, S. A., Parrish, J. T. \& Wan, X. (eds) Environmental/Climate Change in the Cretaceous Greenhouse World: Records from Terrestrial Scientific Drilling of Songliao Basin and Adjacent Area of China. Palaeogeography, Palaeoclimatology, Palaeoecology, 385, $17-30$.

WANG, C. W., LI, N., Sun, Y. W. \& Zong, P. 2011. Distribution of Tuvaella brachiopod fauna and its tectonic significance. Journal of Earth Sciences, 22, 11-19.

Wang, F., Xu, W. L., GaO, F. H., Meng, E., CaO, H. H., ZHAO, L. \& YANG, Y. 2012a. Tectonic history of the Zhangguangcailing Group in eastern Heilongjiang Province, NE China: constraints from $\mathrm{U}-\mathrm{Pb}$ geochronology of detrital and magmatic zircons. Tectonophysics, 566, 105-122.
Wang, F., Xu, W. L., Meng, E., CaO, H. H. \& GaO, F. H. 2012b. Early Paleozoic amalgamation of the Songmen-Zhangguangcai Range and Jiamusi massifs in the eastern segment of the Central Asian Orogenic Belt: geochronological and geochemical evidence from granitoids and rhyolites. Journal of Asian Earth Sciences, 49, 234-248.

WANG, Y., ZHANG, F. Q. ET AL. 2006. Zircon SHRIMP U$\mathrm{Pb}$ dating of meta-diorite from the basement of the Songliao Basin and its geological significance. Chinese Science Bulletin, 51, 1877-1883.

Wilde, S. A., Dorsett-Bain, H. L. \& Lennon, R. G. 1999. Geological setting and controls on the development of graphite, sillimanite and phosphate mineralization within the Jiamusi Massif: an exotic fragment of Gondwanaland located in north-eastern China? Gondwana Research, 2, 21-46.

Wilde, S. A., Zhang, X. Z. \& Wu, F. Y. 2000. Extension of a newly identified 500 Ma metamorphic terrane in North East China: further U-Pb SHRIMP dating of the Mashan Complex, Heilongjiang Province, China. Tectonophysics, 328, 115-130.

Wilde, S. A., Wu, F. Y. \& Zhang, X. Z. 2003. Late PanAfrican magmatism in northeastern China: SHRIMP $\mathrm{U}-\mathrm{Pb}$ zircon evidence from granitoids in the Jiamusi Massif. Precambrian Research, 122, 311-327.

Wu, F. Y., Sun, D. Y., LI, H. M. \& WANG, X. L. 2000. Zircon $\mathrm{U}-\mathrm{Pb}$ ages of the basement rocks beneath the Songliao Basin, NE China. Chinese Science Bulletin, 45, 1514-1518.

Wu, F. Y., Sun, D. Y., LI, H. M. \& WANG, X. L. 2001. The nature of basement beneath the Songliao Basin in NE China: geochemical and isotopic constraints. Physical Chemistry of Earth Part A, 26, 793-803.

Wu, F. Y., YANG, J. H., Lo, C. H., Wilde, S. A., Sun, D. Y. \& JAHN, B. M. 2007a. The Heilongjiang Group: a Jurassic accretionary complex in the Jiamusi Massif at the western Pacific margin of northeastern China. Island Arc, 16, 156-172.

Wu, F. Y., Sun, D. Y., Ge, W. C., Zhang, Y. B., Grant, M. L., WILDE, S. A. \& JAHN, B. M. 2011. Geochronology of the Phanerozoic granitoids in northeastern China. Journal of Asian Earth Sciences, 41, 1-30.

Wu, G., Sun, F. Y., Zhao, C. S., Li, Z. T., Zhao, A. L., PANG, Q. B. \& LI, G. Y. 2005. Discovery of the Early Paleozoic post-collisional granites in northern margin of the Erguna massif and its geological significance. Chinese Science Bulletin, 50, 2733-2743.

Wu, H. Y., Liang, X. D., XIANG, C. F. \& WanG, Y. W. 2007b. Characteristics of petroleum accumulation in syncline of the Songliao basin and discussion on its accumulation mechanism. Science in China Series D, 50, 702-709.

XI, D. P., Wan, X. Q. ET AL. 2011. Discovery of Late Cretaceous foraminifera in the Songliao Basin: evidence from SK-1 and implications for identifying seawater incursions. Chinese Science Bulletin, 56, 253-256.

Xiao, W., Windley, B. F., Hao, J. \& Zhai, M. 2003. Accretion leading to collision and the Permian Solonker suture, Inner Mongolia, China: termination of the central Asian orogenic belt. Tectonics, 22, 1069, http://dx.doi.org/10.1029/2002TC001484

XiaO, W., MaO, Q. eT AL. 2010. Paleozoic multiple accretionary and collisional processes of the Beishan 


\section{EVOLUTION OF CRETACEOUS BASINS, NE CHINA}

orogenic collage. American Journal of Science, 310, 1553-1594.

Xiao, W. J., Kroner, A. \& Windley, B. 2009. Geodynamic evolution of Central Asia in the Paleozoic and Mesozoic. International Journal of Earth Sciences, 98, $1185-1188$.

YanG, Y. C., Han, S. J., Sun, D. Y., Guo, J. \& Zhang, S J. 2012. Geological and geochemical features and geochronology of porphyry molybdenum deposits in the Lesser Xing' an Range-Zhangguangcai Range metallogenic belt. Acta Petrologica Sinica, 28, 379-390.

Yu, J. J., Wang, F., Xu, W. L., Gao, F. H. \& Pei, F. P. 2012. Early Jurassic mafic magmatism in the Lesser Xing' an-Zhangguangcai Range, NE China, and its tectonic implications: constraints from zircon $\mathrm{U}-\mathrm{Pb}$ chronology and geochemistry. Lithos, 142, 256-266.

Yu, X., Xiao, J., Chen, H. L., Zhang, F. Q., Xu, Y. Dong, C. W. \& Pang, Y. M. 2008. Phanerozoic magmatic events in the basement of Songliao basin: SHRIMP dating of captured zircons from Yingcheng Formation volcanic rocks. Acta Petrologica Sinica, 24, 1123-1130

Zhang, F. Q., Chen, H. L. ET AL. 2012. Late MesozoicCenozoic evolution of the Sanjiang Basin in NE China and its tectonic implications for the West Pacific continental margin. In: XiaO, W., Li, S., Santosh, M. \& JAHN, B. (eds) Orogenic Belts in Central Asia: Correlations and Connections. Journal of Asian Earth Sciences, 49, 287-299.

Zhang, Y. Y. \& Bao, L. N. 2009. Cretaceous Phytoplankton Assemblages from Songke Core-1, North and South (SK-1, N and S) of Songliao Basin, Northeast China. Acta Geologica Sinica - English, 83, 868-874.
Zhao, B., Wang, C., Wang, X. \& Feng, Z. 2013. Late Cretaceous (Campanian) provenance change in the Songliao Basin, NE China: evidence from detrital zircon $\mathrm{U}-\mathrm{Pb}$ ages from the Yaojia and Nenjiang Formations. In: Wang, C., Graham, S. A., Parrish, J. T. \& WAN, X. (eds) Environmental/Climate Change in the Cretaceous Greenhouse World: Records from Terrestrial Scientific Drilling of Songliao Basin and Adjacent Area of China. Palaeogeography, Palaeoclimatology, Palaeoecology, 385, 83-94.

Zhou, J. B., Wilde, S. A., Zhang, X. Z., Zhao, G. C., Zheng, C. Q., Wang, Y. J. \& Zhang, X. H. 2009. The onset of Pacific margin accretion in NE China: evidence from the Heilongjiang high-pressure metamorphic belt. Tectonophysics, 478, 230-246.

Zhou, J. B., Wilde, S. A., Zhao, G. C., Zhang, X. Z., WANG, H. \& ZENG, W. S. 2010. Was the easternmost segment of the Central Asian orogenic belt derived from Gondwana or Siberia: an intriguing dilemma? Journal of Geodynamics, 50, 300-317.

Zhou, J. B., Wilde, S. A. ET AL. 2011a. A $>1300 \mathrm{~km}$ late Pan-African metamorphic belt in NE China: new evidence from the Xing'an block and its tectonic implications. Tectonophysics, 509, 280-292.

Zhou, J. B., Zhang, X. Z., Wilde, S . A . \& Zheng, C . Q . 2011b. Confirming of the Heilongjiang similar to $500 \mathrm{Ma}$ Pan-African khondalite belt and its tectonic implications. Acta Petrologica Sinica, 27, 1235-1245.

Zhou, J. B., Wilde, S. A., Zhang, X. Z., LiU, F. L. \& LiU, J. H. 2012. Detrital zircons from Phanerozoic rocks of the Songliao Block, NE China: evidence and tectonic implications. Journal of Asian Earth Sciences, 47, $21-34$. 